\title{
Cloud condensation nuclei closure study on summer arctic aerosol
}

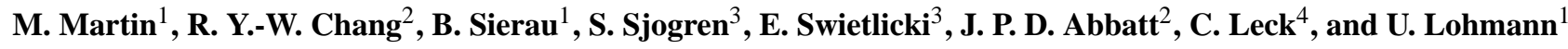 \\ ${ }^{1}$ Institute for Atmospheric and Climate Science, ETH Zurich, Zurich, Switzerland \\ ${ }^{2}$ Department of Chemistry, University of Toronto, Toronto, Canada \\ ${ }^{3}$ Division of Nuclear Physics, Lund University, Lund, Sweden \\ ${ }^{4}$ Department of Meteorology, Stockholm University, Stockholm, Sweden
}

Received: 20 February 2011 - Published in Atmos. Chem. Phys. Discuss.: 14 March 2011

Revised: 6 October 2011 - Accepted: 23 October 2011 - Published: 16 November 2011

\begin{abstract}
We present an aerosol - cloud condensation nuclei (CCN) closure study on summer high Arctic aerosol based on measurements that were carried out in 2008 during the Arctic Summer Cloud Ocean Study (ASCOS) on board the Swedish ice breaker Oden. The data presented here were collected during a three-week time period in the pack ice $\left(>85^{\circ} \mathrm{N}\right)$ when the icebreaker Oden was moored to an ice floe and drifted passively during the most biological active period into autumn freeze up conditions.

$\mathrm{CCN}$ number concentrations were obtained using two $\mathrm{CCN}$ counters measuring at different supersaturations. The

ber concentration with the observed one was achieved when the organic fraction of the aerosol was treated as nearly water insoluble $\left(\kappa_{\mathrm{org}}=0.02\right)$, leading to a mean total $\kappa, \kappa_{\mathrm{tot}}$, of $0.33 \pm 0.13$. However, several settings led to closure and $\kappa_{\text {org }}=0.2$ is found to be an upper limit at $0.1 \%$ supersaturation. $\kappa_{\text {org }} \leq 0.2$ leads to a $\kappa_{\text {tot }}$ range of $0.33 \pm 013$ to $0.50 \pm 0.11$. Thus, the organic material ranges from being sparingly soluble to effectively insoluble. These results suggest that an increase in organic mass fraction in particles of a certain size would lead to a suppression of the Arctic CCN activity.
\end{abstract} directly measured $\mathrm{CCN}$ number concentration was then compared with a $\mathrm{CCN}$ number concentration calculated using both bulk aerosol mass composition data from an aerosol mass spectrometer (AMS) and aerosol number size distributions obtained from a differential mobility particle sizer, assuming $\kappa$-Köhler theory, surface tension of water and an internally mixed aerosol. The last assumption was supported by measurements made with a hygroscopic tandem differential mobility analyzer (HTDMA) for particles $>70 \mathrm{~nm}$.

For the two highest measured supersaturations, 0.73 and $0.41 \%$, closure could not be achieved with the investigated settings concerning hygroscopicity and density. The calculated CCN number concentration was always higher than the measured one for those two supersaturations. This might be caused by a relative larger insoluble organic mass fraction of the smaller particles that activate at these supersaturations, which are thus less good $\mathrm{CCN}$ than the larger particles. On average, $36 \%$ of the mass measured with the AMS was organic mass. At $0.20,0.15$ and $0.10 \%$ supersaturation, closure could be achieved with different combinations of hygroscopic parameters and densities within the uncertainty range of the fit. The best agreement of the calculated CCN num-

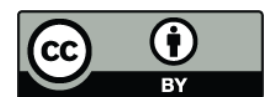

Correspondence to: M. Martin (maria.martin@env.ethz.ch)

\section{Introduction}

Aerosol particles in the atmosphere can influence climate in several ways. Firstly, they can directly scatter and absorb radiation (direct aerosol effect). Secondly, they can act as cloud condensation nuclei $(\mathrm{CCN})$ or ice nuclei and change the properties of clouds, which is called the indirect aerosol effect (see e.g. Lohmann and Feichter, 2005). Both effects are a matter of current research, as aerosol-cloud interaction processes are generally not well understood, and the impact of the various aerosol effects on climate and climate change is still unknown (Denman et al., 2007).

Clouds themselves play a key role in our understanding of the climate system. This is also true for Arctic low level clouds (Walsh et al., 2002; Tjernström et al., 2008). The high Arctic low-level clouds (north of $80^{\circ} \mathrm{N}$ ) have a pronounced influence on the surface energy budget (Sedlar et al., 2010), and thus on the melting and freezing of the perennial experiments indicate that Arctic clouds are optically thicker than elsewhere, predominantly because they tend to include cloud liquid water at much lower temperatures than found elsewhere (e.g. Intrieri et al., 2002; Tjernström et al., 2008). On the opposite, during summer, the high Arctic low-level sea ice (Kay and Gettelman, 2009). During winter, model

Published by Copernicus Publications on behalf of the European Geosciences Union. 
clouds are optically thin with fewer but larger droplets, which make them reflect shortwave radiation less effectively than clouds with numerous but smaller droplets (e.g. Twomey, 1977).

There is also another difference between summer and winter clouds in the Arctic concerning particle sources. This is caused by the geographical location of the Arctic, which exposes it to an influx of polluted mid-latitude air during November to April, reinforced by photochemical oxidation at polar sunrise. In winter to early spring Arctic aerosol concentrations may reach up to 20 times the pre-industrial levels, a phenomenon referred to as Arctic haze (Heintzenberg and Leck, 1994; Shaw, 1995; Korhonen et al., 2008). In contrast to winter, summer conditions are much more pristine, typically resulting in low and relatively stable aerosol concentrations of approximately $20-60 \mathrm{~cm}^{-3}$ in the accumulation mode (Covert et al., 1996; Bigg et al, 1996; Heintzenberg et al., 2006) over the pack ice area north of $80^{\circ} \mathrm{N}$. It is possible that long-range transport of pollutants are also a source then, but during the high Arctic summer: (1) it precipitates more, which lowers aerosol mass and number by scavenging, specifically at the marginal ice zone (Nilsson and Leck, 2002; Heintzenberg et al., 2006); (2) air masses tend to be transported from cleaner regions (Stohl et al., 2006); and (3) during a former campaign it was observed that Aitken mode concentrations are higher than accumulation mode concentrations, which is opposite to winter-time observations (Heintzenberg et al., 2006). All of these findings suggest that the major source of particles in summer is different from that in winter.

Marine biology is proposed to be a source of Arctic summertime CCN (see e.g. Li and Barrie, 1993; Heintzenberg and Leck, 1994; Leck and Persson, 1996; Quinn et al., 2002; Leck and Bigg, 2005a). This source is expected to be more active in summer, as ice melts and more solar radiation reaches the ocean, which leads to increased biological activity. Dimethyl sulphide (DMS), a gas produced by marine organisms, is thought to be a good precursor for CCN (Charlson et al., 1987). It mainly oxidizes photochemically to sulfur dioxide $\left(\mathrm{SO}_{2}\right)$, which reacts in the atmosphere and/or within cloud droplets to form sulfuric acid $\left(\mathrm{H}_{2} \mathrm{SO}_{4}\right)$. Gasphase $\mathrm{H}_{2} \mathrm{SO}_{4}$ is then the suggested precursor for aerosol nucleation, but it also condenses on pre-existing particles. Although the major source region of the aerosol precursor gas, DMS, was confined to the biological open waters at the ice edge, the at least 2-3 days residence time of DMS in air enabled it to be advected over the pack ice area and support it with major $\mathrm{CCN}$ precursor-components through its photochemical oxidation (Leck and Persson, 1996). Furthermore, from research carried out during three ice-breaker expeditions in the summers of 1991, 1996 and 2001 (Leck et al., 1996, 2001, 2004) a new picture of aerosol properties with implications for CCN activation has been suggested (Leck and Bigg, 2005b): DMS concentration would determine the mass of sulfate by producing material for growth of the par- ticles, but would have only a minor influence on the number of $\mathrm{CCN}$ forming the low-level clouds. Instead the number of airborne microcolloids and their gels, called exopolymer secretions (EPS) or microgels, emitted from the surface microlayer of the open leads through bubble bursting mechanisms has been put forward for consideration to mainly contribute to the number of cloud drops over the pack ice area. However, the hygroscopic properties, the cloud nucleating ability of these high Arctic biogenic particles, and their source and sink strengths are still not well understood. However, it has been shown that for marine particles, samples with marine organic matter were less $\mathrm{CCN}$ active than pure ammonium sulfate particles (Moore et al., 2008). Furthermore, seawater enriched with organic matter was found to be less CCN active than pure seawater (Fuentes et al., 2011).

So far, CCN measurements over the high Arctic pack ice area in summer are few due to its remoteness. Bigg and Leck (2001) report daily mean CCN number concentrations of 15 to $50 \mathrm{~cm}^{-3}$ at $0.25 \%$ supersaturation, with a variability over three orders of magnitude within a day, although concentrations were usually lower than $100 \mathrm{~cm}^{-3}$, occasionally less than $1 \mathrm{~cm}^{-3}$ (e.g. Lannefors et al., 1983; Bigg et al., 2001; Leck et al., 2002; Mauritsen et al., 2011). Mauritsen et al. (2011) summarize frequency distributions of observed $\mathrm{CCN}$ number concentrations from four high Arctic expeditions (including the most recent data set collected during ASCOS (Arctic Summer Cloud Ocean Study) in the summer of 2008) measured at different supersaturations (ranging from 0.1 to $0.8 \%$ ). All four populations showed an overall consistent distribution with three quarters of the $\mathrm{CCN}$ number concentrations being greater than $10 \mathrm{~cm}^{-3}$ but less than about $100 \mathrm{~cm}^{-3}$, medians typically in the range of 15 to $50 \mathrm{~cm}^{-3}$. Bigg and Leck (2001) performed a closure study by calculating a predicted CCN number concentration from size distribution data and assuming that the particles consist only of ammonium sulfate. This gave them a good correlation with the measured CCN data, but an overprediction (more CCN were calculated than measured) of around $30 \%$ was determined. To investigate the role of chemistry in more detail, Zhou et al. (2001) performed a closure study using additional hygroscopic growth information and an indirect measure on chemistry, and assuming that the calculated CCN particles were composed of ammonium sulfate, a nearly insoluble fraction and sodium chloride. These assumptions yielded a similar overprediction as found by Bigg and Leck (2001), and the reason remained unclear. Furthermore, Leck et al. (2002) used direct measure of chemical composition, state of mixture and morphology to discuss sources and methods of production of CCN. Measured CCN concentrations were on average less than would have been expected from either a sulfate or a sea-salt composition and the observed particlenumber size distribution. It was concluded that other components, probably organics, depressed the nucleating ability of the particles. However, on clear sky days, there were a majority of occasions on which $\mathrm{CCN}$ concentrations were more 
than predicted from a sulfate composition and the measured number size distribution.

In this paper, we present an aerosol-CCN closure study on data taken during a campaign in the high Arctic on board the Swedish ice breaker Oden in summer 2008. The study focuses on a three-week period, where the ship was drifting passively moored to an ice floe at a latitude $>87^{\circ} \mathrm{N}$, thus during the most biological active period into autumn freeze up conditions. Closure was tested by comparing measured $\mathrm{CCN}$ number concentrations with $\mathrm{CCN}$ number concentrations calculated from combined mass spectrometer chemical mass and particle number size distribution data, using $\kappa$ Köhler theory (Petters and Kreidenweis, 2007). Conclusions can then be drawn on the assumptions made (e.g. concerning the hygroscopicity of the particles and their components) based on the outcome of the closure.

\section{Cruise details}

The ASCOS campaign was carried out on the Swedish ice breaker Oden. The cruise started on 2 August 2008 (Day of Year (DoY) 215) in Longyearbyen, Svalbard. Figure 1 shows the ship track of the cruise. First, the ship headed westwards into the Greenland Sea Fram Strait area where it stopped for an open water station on 3 August (DoY 216). After that, the cruise was continued northwards through the marginal ice zone, where measurements were taken from 4 August (DoY 217) to 5 August (DoY 218). From there, Oden went north through the pack ice until it was docked on the ice floe at around $87^{\circ} \mathrm{N}$ on 12 August (DoY 225), 12:00. Then the ship drifted with the ice floe for three weeks until 2 September (DoY 246), 00:10, reaching a latitude of $87^{\circ} 30^{\prime} \mathrm{N}$. From there, Oden returned to Longyearbyen on 9 September (DoY 254). On the way back, an additional marginal ice zone station (6 September (DoY 251) to 7 September) and an open water station (7 September (DoY 252)) were conducted. For further cruise details see Paatero et al. (2009). The study presented here uses only data that were collected during the ice drift period.

\section{Instrumentation}

\subsection{Inlet system}

All four expeditions mentioned in the introduction used the same sampling manifold upstream of the aerosol measurements. Leck et al. (2001) reported further details. In short, the inlet system consisted of two masts which were equipped with a horizontally oriented commercial $\mathrm{PM}_{1}$ and $\mathrm{PM}_{10^{-}}$ inlet, respectively. The $\mathrm{PM}_{1}$-inlet mast was also used for the gas-phase sampling lines. The inlets were located approximately $25 \mathrm{~m}$ above sea level as on previous cruises. The air was drawn in via pipes of the two-masted inlet system that extended at an angle of $45^{\circ}$ to about $3 \mathrm{~m}$ above the roof of the container. All aerosol instruments used for this study were located in the same container on the forth deck of the ship and sampled from the same $\mathrm{PM}_{10}$ inlet through the main pipe that had an inner diameter of $9 \mathrm{~cm}$ and was pumped with a total flow of approx. $11401 \mathrm{~min}^{-1}$. Only the CCN counter measuring at a constant supersaturation (see below) sampled from the $\mathrm{PM}_{1}$ inlet during selected time periods. The individual particle instruments were served by two distribution lines of $3 / 8$ inch stainless steel tubing that were branched off the main pipe. Aerosol samples were taken isokinetically from the main flow using forward pointing inlets located in the center of the main pipe and connected to the two distribution lines. For each of these inlets and distribution lines, a constant volume flow was generated both from the instruments and a variable back-up flow leading to a total of $16.71 \mathrm{~min}^{-1}$. With the inlets facing forward and by positioning the ship facing into the wind, local ship pollution could be avoided most of the time. Additionally, direct contamination from the ship was excluded by using a pollution controller. When either sudden high particle number concentrations were detected by an ultrafine particle counter (UCPC; TSI model 3025; TSI Inc., MN, USA) located upstream of the flow splits to the counters and/or the wind was outside $\pm 70^{\circ}$ of the direction of the bow and weaker than $2 \mathrm{~m} \mathrm{~s}^{-1}$, the main pumps were turned off and pollution could not reach the sample inlets.

The CCN counters were also connected to the main pipe via one of the distribution lines. The connection had a length of $103 \mathrm{~cm}$ plus an additional $105 \mathrm{~cm}$ of conductive tubing ( $6 \mathrm{~mm}$ outer diameter) that was branched off the steel tube using a tee. The minor flow split was shared by the two CCN counters and a Condensation Particle Counter (CPC). Each of the CCN counters had a sample flow of $0.51 \mathrm{~min}^{-1}$, and the CPC had an additional flow of $0.91 \mathrm{~min}^{-1}$. The RH of the sample flow was assumed to be less than $40 \%$ based on the residence time of the air inside the flow system and the temperature difference between ambient and laboratory temperature and on measurements made close to the inlet inside the container.

Diffusional losses of particles inside the tubing section from the isokinetic inlet of the distribution line to the CCNCs were calculated to be in the range of $5 \%$ for a $30 \mathrm{~nm}$ diameter particle. As diffusional losses decrease with increasing particle size, these losses were neglected and not corrected for herein.

Gravitational losses of particles $>1 \mu \mathrm{m}$ diameter have been neglected in our considerations as particles of this size have been barely observed during the cruise. Gravitational settling of $1 \mu \mathrm{m}$ diameter particles would account for approx. $1 \%$ loss in a $90^{\circ}$ bend section (assuming the flow conditions for the distribution-lines described above), and for less than $1 \%$ in the straight tube sections from the isokinetic sampling manifold to the CCN-tee. The flow system included five $90^{\circ}$ bend sections. 
Table 1. The different measured supersaturations throughout the study. For simplicity, the mean values from counter 1 are used in the manuscript. All closure calculations were done using the respective mean supersaturation for each point in time.

\begin{tabular}{lrrrrrr}
\hline & Time Period & SS 1 [\%] & SS 2 [\%] & SS 3 [\%] & SS 4 [\%] & SS5 [\%] \\
\hline Counter 1 & $07 / 08-10 / 08$ & $0.089 \pm 0.006$ & $0.161 \pm 0.009$ & $0.233 \pm 0.013$ & $0.521 \pm 0.045$ & $0.952 \pm 0.094$ \\
& $10 / 08-12 / 08$ & $0.082 \pm 0.006$ & $0.126 \pm 0.007$ & $0.171 \pm 0.009$ & $0.347 \pm 0.026$ & $0.613 \pm 0.056$ \\
& $12 / 08-21 / 08$ & $0.102 \pm 0.007$ & $0.146 \pm 0.008$ & $0.189 \pm 0.010$ & $0.362 \pm 0.028$ & $0.622 \pm 0.058$ \\
& $21 / 08-08 / 09$ & $0.106 \pm 0.007$ & $0.158 \pm 0.009$ & $0.210 \pm 0.010$ & $0.416 \pm 0.034$ & $0.725 \pm 0.069$ \\
mean values & & 0.10 & 0.15 & 0.20 & 0.41 & 0.73 \\
\hline Counter 2 & $04 / 08-15 / 08$ & & $0.170 \pm 0.010$ & & & \\
& $15 / 08-08 / 09$ & & & $0.219 \pm 0.009$ & & \\
\hline
\end{tabular}

\subsection{CCN counters}

The instrument used to measure the CCN number concentration was a continuous-flow streamwise thermal gradient $\mathrm{CCN}$ counter (CCNC). It is built and distributed by Droplet Measurement Technologies (DMT, Boulder USA), and used by several research groups worldwide. Its working principle is described in full detail by Roberts and Nenes (2005).

The main part of the instrument is a cylindrical, upright standing column. An inside temperature gradient is established, with the lowest temperature at the top. The walls of this column are wetted with water. Thus, heat and water vapor are transported towards the center of the column by diffusion. As heat diffuses more slowly than water in air in the temperature range used, a constant supersaturation $(S S)$ is established in the center of the column. This supersaturation can be adjusted by changing the temperature gradient of the column.

Aerosol particles enter the instrument through an inlet at the top and pass through the column where they can activate and grow to droplet size. At the outlet of the column the activated particles are counted with an optical particle counter (OPC) and collected in different size bins. All particles larger than $1 \mu \mathrm{m}$ in diameter are considered as cloud condensation nuclei. The CCNC undercounts particles, if they have not grown larger than $1 \mu \mathrm{m}$ by the time they reach the OPC. However, in the study presented here, most particles were found in size bins larger than $1 \mu \mathrm{m}$, and were thus counted correctly as $\mathrm{CCN}$.

The temperature determining the supersaturation of the instrument was calibrated several times during the cruise for both counters using monodisperse ammonium sulfate particles, which have a known activation curve. The particles are first size-selected using a differential mobility analyzer, and then passed through the DMT CCNC. As the particle size increases, the activated fraction increases. From a certain size onwards, all particles activate. The dry activation diameter $\left(D_{\mathrm{d}}\right)$ is defined as the size at which $50 \%$ of the particles activate, and can be determined by fitting the activated fraction versus the dry particle size. The critical supersaturation $S_{\text {crit }}$ can then be calculated using Köhler theory. It is used as a calibration value for the measured SS. A detailed description on calibrating the DMT CCNC can be found in Rose et al. (2008).

During this study, two CCN counters were operated in parallel. The first counter (counter 1) scanned five different $S S$ with a measurement period of $30 \mathrm{~min}$ each. The settings of this counter were adjusted after each calibration, i.e. several times during the cruise. Thus, the supersaturations at which $\mathrm{CCN}$ properties are presented herein varies for different time periods. Difficulties in calibrating the $\mathrm{CCN}$ counters were encountered on board the ship that led to a relatively large uncertainty in the supersaturations of $6-10 \%$. The difficulties were mainly due to problems with the particle generation system. Furthermore, the flow ratio of the sheath to the sample flow was around 13:1 instead of the ideal 10:1 because of problems caused by the flow measurement. The second CCN counter (counter 2) was set to a constant supersaturation, which was slightly increased once for better comparison with $\mathrm{CCN}$ data collected during three former expeditions. The values of the supersaturations of both counters are summarized in Table 1 . The two counters compare very well, although their exact supersaturations differs. This is shown in more detail in Sect. 5. The instruments were deployed in parallel with a Condensation Particle Counter (CPC 3785, TSI Inc., MN, USA), which measured the total number of aerosol particles larger than $5 \mathrm{~nm}$ in diameter.

\subsection{Aerosol mass spectrometer}

A unit-mass resolution time-of-flight (C-ToF) aerosol mass spectrometer (AMS, Aerodyne Research Incorporated, Billerica, USA) sampled ambient particles from $100 \mathrm{~nm}$ to $500 \mathrm{~nm}$ vacuum aerodynamic diameter with near $100 \%$ transmission efficiency. The lower end of the vacuum aerodynamic diameters, $100 \mathrm{~nm}$, converts to a geometric diameter of $67 \mathrm{~nm}$ when assuming that the particles have a density of $1.5 \mathrm{~g} \mathrm{~cm}^{-3}$. Particles were vaporized and ionized $(70 \mathrm{eV})$ in a vacuum chamber and the resulting species were detected with a time-of-flight mass spectrometer. The detected signal was attributed to sulphate, nitrate, organics and methane sulphonate that was non-refractory at $10^{-7}$ torr and $873 \mathrm{~K}$, in 


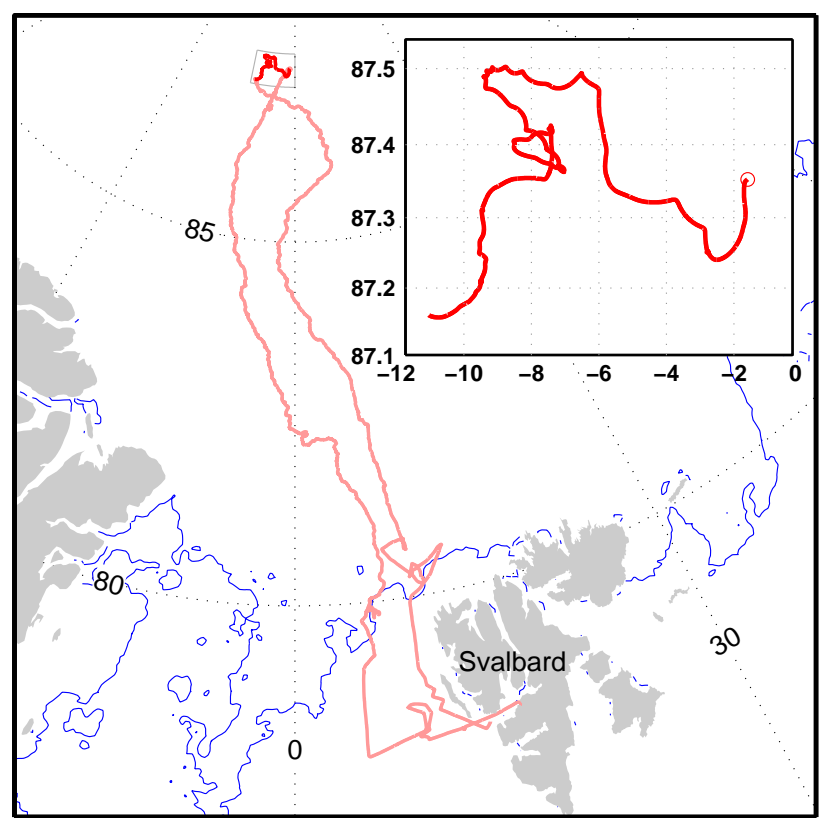

Fig. 1. The cruise route of Oden, enlarged is the time of the drift with the ice floe.

order to determine the particle chemical composition. This study makes use of the bulk aerosol chemical composition which was averaged over a sampling time of $5 \mathrm{~min}$. Further details on the instrument's general operation can be found in the literature (Canagaratna et al., 2007; Drewnick et al., 2005; Jimenez et al., 2003), and the specific details for this study can be found in Chang et al. (2010). Although cascade impactor measurements with 6-24 h time resolution on aerosol chemical composition resolved over size were also available, the AMS data were chosen for this analysis due to its relatively higher time resolution.

\subsection{Twin differential mobility particle sizer}

To measure the particle number size distribution one large and one small Hauke-type differential mobility analyzer were run in parallel (TDMPS) to cover the mobility size range 3$800 \mathrm{~nm}$ in diameter. The small DMA was set to a sample to sheath air flow ratio of 2:20, the large DMA to a ratio of 1:5, with a total flow rate of $31 \mathrm{~min}^{-1}$. Three mobility channels overlapped between the two DMAs to give a continuous number size distribution (Birmili et al., 1999).

The CPC on the same flow split as the CCN counters measured on average $20 \%$ less than the TDMPS system, when integrating the TDMPS data from the cut-off of the CCNCCPC. One part of this difference can be explained by particle losses due to diffusion as the CPC was located further down the line than the TDMPS. These losses accounted for $\approx 5 \%$ (calculated for $30 \mathrm{~nm}$ diameter particles), but cannot explain the difference of $20 \%$. As the cut-off of the CCNC-CPC was not calibrated and the CPC also had some instrumen- tal issues, the integrated number concentration of the quality assured TDMPS system was finally used for the data and error analysis presented herein. The TDMPS measurements agreed well with parallel measurements with another DMPS system and a UCPC which were performed during the cruise in the same laboratory.

\subsection{Hygroscopic tandem differential mobility analyzer}

The hygroscopic properties at subsaturated conditions were measured with a hygroscopic tandem differential mobility analyzer (HTDMA) constructed at Lund University which was specifically constructed for long term measurements, in accordance with the design and operation criteria decided within the EU FP6 Infrastructure Project EUSAAR. The aerosol was charged with an ${ }^{85} \mathrm{Kr}$ diffusion charger before it entered the first DMA (DMA1), a Vienna type, $28 \mathrm{~cm}$ long, which was housed in an insulated box at a well defined temperature, typically $25^{\circ} \mathrm{C}$.

The RH upstream of DMA1 was always lower than $30 \%$. In DMA1 a fixed voltage was applied, corresponding to a certain dry size, or more precisely to a certain electrical mobility. Downstream of DMA1, the aerosol was monodisperse, meaning that it had a mobility distribution corresponding to the transfer function of DMA1. The flow ratio between the aerosol and the sheath flow was set to $1: 10$, to minimize broadening of the spectrum. After DMA1, the aerosol passed through GORE-TEX tubing, with temperature controlled water flowing on the outside of the membrane in opposite direction. The water migration through the membrane was controlled by the temperature of the water. After this conditioning unit, the aerosol sample flow was directed into a second housing, with a temperature of several degrees lower than the first. Since the saturation vapor pressure of the water decreases with temperature, the $\mathrm{RH}$ increased before it entered the second DMA (DMA2). By using a closed loop for the sheath and excess flow, the RH inside DMA2 asymptotically approaches the RH of the aerosol entering the DMA.

By ensuring a well controlled temperature set at 16$20^{\circ} \mathrm{C}$ (changed at a few occasions during the campaign), the DMA2 RH was kept at $90 \%$ (accuracy $\pm 1.2 \% \mathrm{RH}$ ). The residence time after the humidifier was 1 secs, after which the voltage in DMA2 was continuously scanned over sizes corresponding to diameter growth factors of $0.85-2.5$, to ensure that no particles were missed. The particles were detected downstream DMA2 using a Condensation Particle Counter (CPC) (TSI, USA). In this case the dry diameters selected were $31,50,72,108,163$ and $263 \mathrm{~nm}$, with two scans of 300 s per size (one up- and one down scan), making the time resolution of the measurements roughly one hour. For more details see also Fors et al. (2011) and Gysel et al. (2009). 


\subsection{Error analysis}

The uncertainty of the CCNC measurements is mainly due to the uncertainty of the set supersaturation, which was calibrated several times. These calibrations showed a uncertainty of $5-10 \%$ depending on the supersaturations (see Table 1 for exact values). The calculated uncertainty of the TDMPS system was based on taking Poisson statistics for the measured number concentrations. Uncertainties in the measured AMS mass at each mass-to-charge ratio were estimated from the electronic noise and Poisson statistics for the ion signal. The uncertainty for each species was then determined by adding in quadrature the uncertainty in its component mass-to-charge ratios.

In terms of intercomparison and the total $\mathrm{CCN}$ number concentration there is also an error due to diffusion losses in the inlet tubing of the instruments. The three instruments were located at different spots in the aerosol container connected to the main inlet using different tubing diameters and lengths. Therefore, this error is size-dependent. It was determined to be $\approx 5 \%$ for $30 \mathrm{~nm}$ diameter particles from the main inlet to the $\mathrm{CCN}$ counters. The error decreases with increasing size, as diffusion losses become smaller.

\section{Analysis}

\subsection{Theory}

Köhler theory describes the relationship between chemical composition, size and supersaturation present at the surface of the droplet in thermodynamic equilibrium. The theory takes into consideration different fundamental properties of a particle, such as surface tension and density. Using this theory, the droplet size of a growing CCN particle can be calculated at a certain $S S$ assuming thermodynamic equilibrium with the environment of the droplet. Köhler theory also provides the critical supersaturation $\left(S_{\text {crit }}\right)$ that must be overcome before a particle of a certain dry size can activate (e.g. Seinfeld and Pandis, 1998). When keeping all other parameters constant, the larger the particle diameter is, the lower critical supersaturation is required for activation.

The supersaturation (SS) can be written, depending on the water activity $a_{\mathrm{w}}$, as follows:

$S S=a_{\mathrm{w}} \exp \left(\frac{4 \sigma_{s / a} M_{\mathrm{w}}}{R T \rho_{\mathrm{w}} D}\right)$,

where $\sigma_{s / a}$ is the surface tension between the solution and air, $\rho_{\mathrm{w}}$ the density of water, $M_{\mathrm{w}}$ its molecular weight, $R$ the universal gas constant, $T$ the absolute temperature, $D$ the diameter of the droplet at the supersaturation $S S$, and $a_{\mathrm{w}}$ the activity of water.

This formula can be reformulated using the hygroscopicity parameter $\kappa$, as defined by Petters and Kreidenweis (2007), leading to:
$S S=\frac{D^{3}-D_{\mathrm{d}}^{3}}{D^{3}-D_{\mathrm{d}}^{3}(1-\kappa)} \exp \left(\frac{4 \sigma_{s / a} M_{\mathrm{w}}}{R T \rho_{\mathrm{w}} D}\right)$,

where $D_{\mathrm{d}}$ is the volume equivalent diameter of the dry particle. $\kappa$ depends on the water activity of the particle and the volumes of the dry particle and of the aerosol. It ranges between 0 for insoluble particles, and values $>1$ for some salts $(1.28$ for $\mathrm{NaCl}) . \kappa$ of a particle is defined as the sum of the products of the $\kappa$ values of all single solute components $i$ in the particle and their corresponding volume fractions $\epsilon_{i}=\frac{V_{i}}{V_{\text {tot }}}$ :

$\kappa_{\mathrm{tot}}=\sum_{i} \epsilon_{i} \kappa_{i}$.

\subsection{Estimation of $\mathrm{CCN}$ number concentrations/ closure study}

To predict the number of $\mathrm{CCN}$, first $\kappa_{\text {tot }}$ (Eq. 3) needs to be calculated. Therefore, $\kappa$ values and densities for the separate mass components measured by the AMS have to be assumed. As organic and sulfate were the two most abundant constituents measured by the AMS (on average $36 \%$ and $52 \%$ of the total mass, respectively), only those two were considered for this closure analysis. For each mass component one $\kappa$ value and one density was chosen. As the AMS measures the bulk chemical composition, all particles are assumed to be internally mixed. The hygroscopic measurements from the HTDMA support the assumptions of an internal mixture over the size range investigated with a slightly decreasing hygroscopicity with decreasing size. Furthermore, Kammermann et al. (2010) showed in a study from the sub-Arctic region that their $\mathrm{CCN}$ predictions were not weakened by assuming an internally mixed aerosol compared to an external mixture.

Next, the supersaturation set in the CCNCs at a given time is taken as the critical supersaturation $S_{\text {crit }}$. With these two parameters, the Köhler equation can be solved analytically for the dry activation diameter $D_{\mathrm{d}}$.

The number of predicted $\mathrm{CCN}, \mathrm{CCN}_{\text {pred }}$, can now be calculated from the TDMPS size distribution data, assuming that all particles with a diameter larger than $D_{\mathrm{d}}$ act as CCN. In an ideal case, i.e. if the assumptions concerning hygroscopicity, density and the internal mixture of the aerosol are correct, $\mathrm{CCN}_{\text {pred }}$ should be equal to the measured number of $\mathrm{CCN}, \mathrm{CCN}_{\text {meas }}$.

For each $S S$, the parameters $\kappa_{\text {org }}, \kappa_{\text {sulf }}, \rho_{\text {org }}$ with the addition of an assumed insoluble fraction of the organic compound (see Table 2) were permuted for sensitivity tests and a more statistical approach. This led to a total set of $90 \mathrm{cal}-$ culations per supersaturation, thus 450 settings in total for counter 1. For each set, $\mathrm{CCN}_{\text {pred }}$ was calculated and the slope of the fit of $\mathrm{CCN}_{\text {pred }}$ vs. $\mathrm{CCN}_{\text {meas }}$ was determined. $\kappa_{\text {org }}$ 
Table 2. Table with the different parameter values for the performed closure studies. For a detailed listing of the different permutations, see Table A1.

\begin{tabular}{lrr}
\hline Parameter & Unit & investigated values \\
\hline$\kappa_{\text {org }}$ & & $0,0.1,0.2,0.3,0.4$ \\
$\kappa_{\text {sulf }}$ & & $0.61,0.65,0.7$ \\
$\rho_{\text {org }}$ & {$\left[\mathrm{g} \mathrm{cm}^{-3}\right]$} & $1,1.2,1.6$ \\
insoluble organic fraction & & $0 \%, 20 \%$ \\
\hline
\end{tabular}

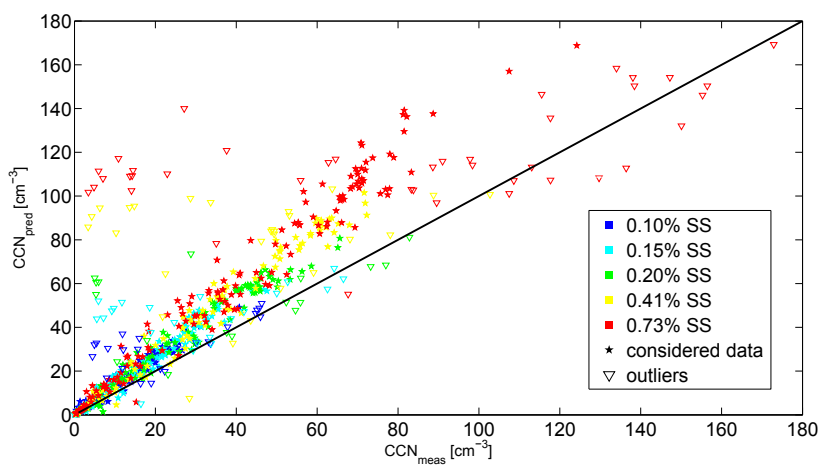

Fig. 2. Sample result of the closure study for permutation $62\left(\kappa_{\mathrm{org}}=\right.$ $0.3, \kappa_{\text {sulf }}=0.65, \rho_{\text {org }}=1 \mathrm{~g} \mathrm{~cm}^{-3}$, no insoluble organic fraction assumed). The closure is overpredicted for all five supersaturations.

was varied assuming organic substances with very different hygroscopicities. We used $\kappa_{\text {org }}=0$ for completely insoluble organic compounds, $\kappa_{\text {org }}=0.1$ and $0.2\left(\kappa_{\text {org }}\right.$ assumed for most lab-produced secondary organic aerosol (Andreae and Rosenfeld, 2008, and references therein)) and $\kappa_{\text {org }}=0.3$ and 0.4 for even more hygroscopic organic fractions. Additionally, the density of the organic substances, $\rho_{\text {org }}$, was varied between $1 \mathrm{~g} \mathrm{~cm}^{-3}, 1.2 \mathrm{~g} \mathrm{~cm}^{-3}$ and $1.6 \mathrm{~g} \mathrm{~cm}^{-3}$. $\kappa_{\text {sulf }}$ for the sulfate particles was changed between $0.7,0.65$ and 0.61 , which are values for different typical sulfate compounds. Petters and Kreidenweis (2007) list as $\mathrm{CCN}$ derived $\kappa_{\text {sulf }}=$ 0.61 for $\left(\mathrm{NH}_{4}\right)_{2} \mathrm{SO}_{4}, \kappa_{\text {sulf }}=0.65$ for $\left(\mathrm{NH}_{4}\right)_{3} \mathrm{H}\left(\mathrm{SO}_{4}\right)_{2}$, and $\kappa_{\text {sulf }}=0.7$ was taken as a mean value for $\mathrm{H}_{2} \mathrm{SO}_{4}$. Moreover, it was assumed that $0 \%$ or $20 \%$ of the organic substance is insoluble with a density $\rho_{\text {ins }}$ of $1 \mathrm{~g} \mathrm{~cm}^{-3}$. All permutations are listed in the Appendix in Table A1. Surface tension of water $\left(0.072 \mathrm{~N} \mathrm{~m}^{-1}\right.$ at the given temperature in the laboratory) was assumed for all calculations. Marine organics have been shown before to have only low surfactant properties (Fuentes et al., 2011), which supports this assumption. Furthermore, lowering the surface tension would lead to an even higher overprediction than already found in this study when using the surface tension of water and thus is unlikely.

For the closure study presented herein, CCNC, TDMPS and AMS data are averaged over $10 \mathrm{~min}$. Data points were only considered, when there was full coverage over $10 \mathrm{~min}$ for all three instruments.

\section{Results and discussion}

Figure 2 shows the results of an closure calculation for $\mathrm{CCN}$ counter 1 (scanning through five supersaturations). This figure is shown as an example to illustrate how closure was calculated. Herein, we assumed a $\kappa_{\text {org }}$ value of 0.3 , a density of the organic compound of $\rho_{\text {org }}=1 \mathrm{~g} \mathrm{~cm}^{-3}, \kappa_{\text {sulf }}$ of 0.65 , and a density of $\rho_{\text {sulf }}=1.77 \mathrm{~g} \mathrm{~cm}^{-3}$. No insoluble organic fraction was assumed. For this setting, the calculated CCN number concentration is overpredicted (higher number concentration than the measured one) for all five supersaturations, mostly for the two highest supersaturations of $0.41 \%$ and $0.73 \%$.

In the whole study, fitting of $\mathrm{CCN}_{\text {pred }}$ vs $\mathrm{CCN}_{\text {meas }}$ was done using a least trimmed squares (LTS) fit, introduced by Rousseeuw (1984). This is a robust fitting method using a least square method, which minimizes the number of $\mathrm{h}$ smallest residuals, where $\mathrm{h}$ is a subset of the total number of points $n$ (here, $h=0.75 n$ ) (for more details see Rousseeuw and van Driessen, 2006 and Muhlbauer et al., 2009). The LTS fit was chosen as it gives more robust results as a simple linear fit. This method also identifies outliers, which are excluded from the fit and thus cannot influence the slope of the fit. These outliers can then be investigated and interpreted separately. In the closure shown above, the slope and $R^{2}$ of the LTS fit for $0.1 \%$ SS was 1.29 and 0.98 , respectively, and for $0.7 \%$ $S S$ it was 1.51 and 0.99 , respectively.

To constrain the best estimate for the four investigated parameters for all five supersaturations, permutation runs as described in Sect. 4.2 were performed. In Fig. 3, the results are shown for each individual supersaturation with the different assumptions listed in Table 2. The number of predicted $\mathrm{CCN}$ increases mainly with increasing $\kappa_{\text {org }}$, as it has the largest range of the four varied parameters. As the criterion for achieving closure we took the slope being 1 within the error bars. The latter were derived from error propagation from the uncertainties described in Sect. 3.6 and then fitting $\mathrm{CCN}_{\text {pred }}$ vs. $\mathrm{CCN}_{\text {meas }}$ by adding and subtracting the absolute errors from the found values. The largest variation from the fit without errors was taken as the uncertainty. $R^{2}$ was always $>0.97$ for all runs and thus not very variable. Based on the above mentioned criterion, closure could be achieved for different settings assuming $\kappa_{\text {org }}=0,0.1$ or 0.2 for some calculations at $0.10 \%$ SS (namely settings $1-6,9-12,15-18$, 19-23, 25-37, 39, 43-45, 47, 49-53; which are defined in Table A1). For $0.15 \%$ and $0.20 \%$ SS, closure could only be achieved with $\kappa_{\text {org }}=0$ with settings 13 and 14 .

The number of outliers given by the LTS fit can also indicate the quality of the fit. At $0.1 \%$ SS, the number of outliers is smallest for the lowest run numbers, thus also suggesting a low $\kappa_{\text {org }}$, while for the higher supersaturations, it does not change significantly between the permutations. The fewest outliers for $0.1 \% S S$ were found for permutation $6\left(\kappa_{\mathrm{org}}=0\right.$, $\left.\rho_{\text {org }}=1.6 \mathrm{gcm}^{-3}, \kappa_{\text {sulf }}=0.7\right)$.

For the two highest measured supersaturations, $0.41 \%$ and $0.73 \%$ SS, calculations overpredicted the CCN number for 


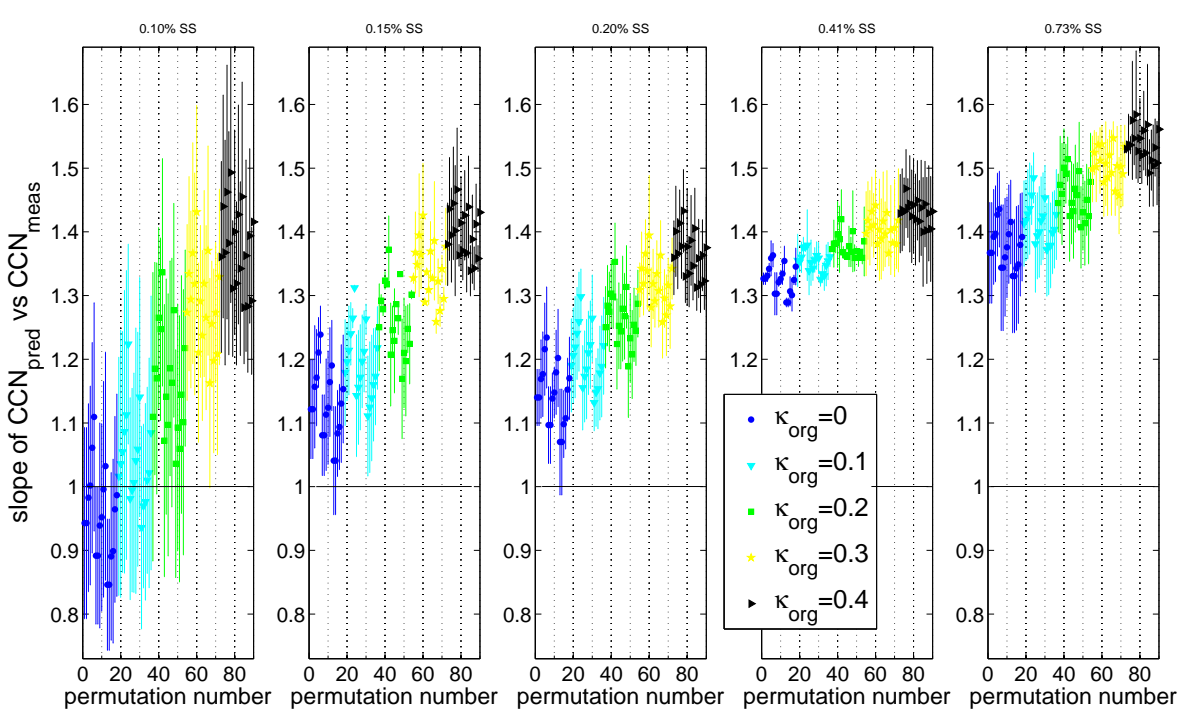

Fig. 3. The fitted slope of $\mathrm{CCN}_{\text {pred }}$ vs. $\mathrm{CCN}_{\text {meas }}$ for the different permuted assumptions and each supersaturation.

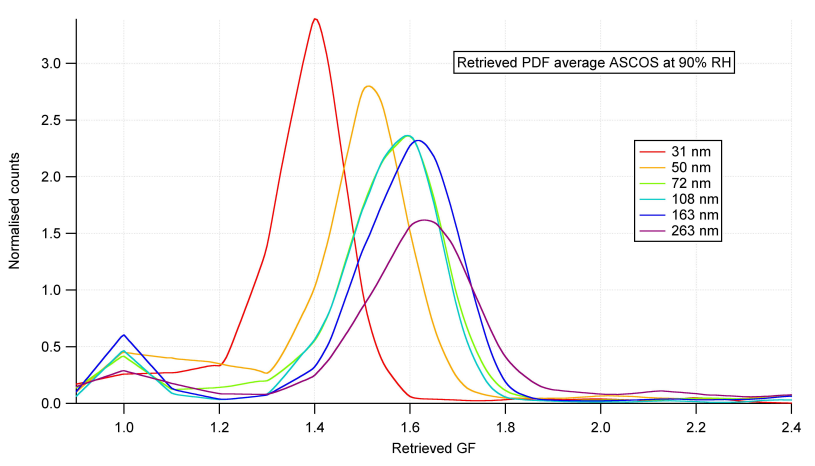

Fig. 4. Average probability density functions for the hygroscopic growth factor (GF, at $90 \%$ relative humidity) during the pack ice drift period. Dry particle diameters investigated are indicated in legend.

all applied permutations. This might be explained by the fact that the lower cut-off of the AMS measurements is $70 \mathrm{~nm}$, but smaller particles can still act as $\mathrm{CCN}$ at these supersaturations. This induces an uncertainty associated with the actual mass concentrations used to calculate $\kappa$, as the ratio of the masses might be different for smaller sizes. As closure cannot be achieved with any of the permutations (even when a $20 \%$ insoluble organic fraction is assumed), these results suggest that the chemical composition was different for smaller particles. They need to have a larger organic fraction to achieve closure. To account for the case in which a nonhygroscopic component of the aerosol was present but not measured by the AMS, further testing was done by adding a non-hygroscopic organic mass with a density of $1 \mathrm{~g} \mathrm{~cm}^{-3}$ to the total mass. However, closure could only be achieved for $0.71 \% S S$ when this insoluble mass was 4 to 5 times higher than the actual measured organic mass. Based on comparisons of mass measured by the AMS and TDMPS, it is unlikely that there was this much mass not measured by the AMS for particles $>100 \mathrm{~nm}$ in diameter. However, for Aitken mode particles or smaller, this would be possible within the measurement uncertainties. It should also be mentioned that at smaller sizes the systematic errors increase (e.g. the AMS composition accuracy, more particle losses), thus, these results at the two highest $S S$ can also be caused at least partly - by these errors.

The HTDMA data (from the Lund University unit) is shown in Fig. 4. In general a mono-modal growth factor distribution was observed. The growth factor for accumulation mode particles was measured to 1.6 with data corrected to $90.0 \% \mathrm{RH}$. The RH accuracy is $\pm 1.2 \% \mathrm{RH}$ at this RH. The hygroscopicity of pure ammonium sulphate is 1.69 at this RH (at $20^{\circ} \mathrm{C}$ ) and for dry diameter $100 \mathrm{~nm}$. The measured hygroscopicity decreased with decreasing size, and an average growth factor of 1.4 was measured for dry particle diameter $31 \mathrm{~nm}$, indicating an increasing fraction of less hygroscopic material. The average growth factor distributions do not represent the mixing state at a certain time; in general an internal mixture was observed. The external mix seen in Fig. 4, with a less hygroscopic mode at GF 1.0, originates mainly from the time period DoY 243.5-246. The two modes were equally important, i.e. an important amount of non-hygroscopic particles, for all sizes, was present during this time period.

The best result for the three lowest supersaturations $(0.10 \%, 0.15 \%$, and $0.20 \%)$, when taking the smallest summed difference from each fitted slope to 1 as criteria, was achieved for setting 13 with $\kappa_{\text {org }}=0, \kappa_{\text {sulf }}=0.61$, and $\rho_{\text {org }}=1 \mathrm{~g} \mathrm{~cm}^{-3}$. Thus, a $\kappa_{\text {org }}$ of 0 has to be assumed. The fractions of outliers with these settings were between $13 \%$ to $21 \%$ for the different supersaturations. To investigate the 

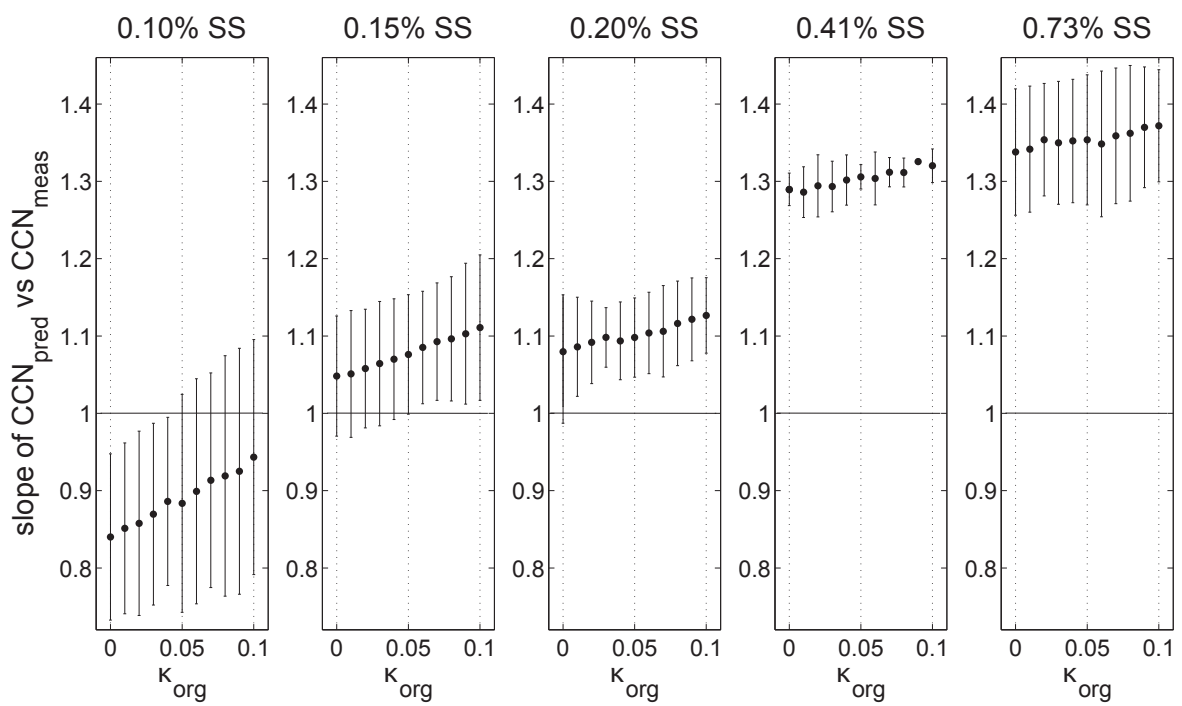

Fig. 5. The slope of $\mathrm{CCN}_{\text {pred }}$ vs. $\mathrm{CCN}_{\text {meas }}$ for permutation $13\left(\kappa_{\text {sulf }}=0.61, \rho_{\text {org }}=1 \mathrm{~g} \mathrm{~cm}^{-3}\right)$, varying $\kappa_{\text {org }}$ between 0 and 0.1 .

value of $\kappa_{\text {org }}$ further, more sensitivity tests with the same values for $\kappa_{\text {sulf }}$ and $\rho_{\text {org }}$ were conducted only varying $\kappa_{\text {org }}$ between 0 and 0.1 in steps of 0.01 . The results are shown in Fig. 5. For the two lowest supersaturations, closure can be achieved within the uncertainties for various $\kappa_{\text {org }}$ values between 0 and 0.1 . However, taking the smallest difference as described before leads to a best fit for $\kappa_{\text {org }}=0.02$, a slightly more hygroscopic value than assumed before.

For the lowest three supersaturations, the results suggest that the measured organic compounds were not or only sparingly soluble and that the ability of the particles to activate as $\mathrm{CCN}$ is dominated by the sulphate part of the particles. This might also be interpreted as such particles analyzed by Leck and Bigg (2005a), which consisted of small insoluble organic particles coming from the surface microlayer, with sulfur-containing gases condensed onto them. The insoluble organic particles were mostly chains or aggregated balls.

These results contradict the findings of Lohmann and Leck (2005), who modeled CCN concentrations that were measured on a former ship cruise (AOE-96) in the high Arctic. For measurements during about 6 days in the pack ice, they needed to assume particles that are as surface active as nonanoic acid to be able to model the measured concentrations. They therefore assumed an external mixture of nonanoic acid and soluble adipic acid or an internal mixture of the measured substances and nonanoic acid, which was mainly at the surface of the particles. Days with about similar meteorological conditions were encountered at the last days of the ASCOS study on the ice floe.

Consistent aerosol properties with our findings have been reported from the North Atlantic (Facchini et al., 2008). They found that the organic matter of submicron particles was almost entirely water insoluble and that the organic matter content increased with decreasing diameter of the parti- cles. Furthermore, Ceburnis et al. (2008) presented a study of clean marine air at Mace Head, Ireland, where water insoluble organic carbon showed a net production at the surface in clean marine air, pointing to a primary origin. This is consistent with our findings that the $\kappa$ of the organic component is close to zero. However, one must keep in mind that these measurements were made over open ocean and are thus not directly comparable to our measurements. Flux measurements at an open lead carried out during the ASCOS campaign showed that particles coming from the sea surface cannot account for the total observed particle number variation in the surface mixing layer at the position of the icebreaker (Held et al., 2010). Hence, one might speculate that, as particles sources over the pack ice area seem to be weak, the measured slightly hygroscopic particles are transported from the open ocean water south of and along the ice edge. Note that the data from the open lead represent point measurements whereas the sampling at the ship is an integrated measurement from all contributing sources.

The results are still ambiguous as the best values for $\kappa_{\text {org }}$ and $\kappa_{\text {sulf }}$ differ depending on the supersaturation. For $0.10 \%$ $S S$, closure could be achieved with $\kappa_{\text {org }}=0,0.1$, and 0.2 . At this $S S$, only the largest particles (>100 nm diameter) activate, for which diffusion losses are smallest and also the AMS measurements should be the most reliable. Therefore, 0.2 can be taken as an upper limit for $\kappa_{\text {org }}$ based on our data. Assuming $\kappa_{\text {org }} \leq 0.2$ and assuming the surface tension of water, implies, that an increase in the organic fraction of the particles leads to a suppression of CCN activity for a given particle size. These results agree well with results by Leck et al. (2002), who found for particles measured in the high Arctic a depression in $\mathrm{CCN}$ activity compared to pure sulfate or sea salt particles. They concluded that this was probably caused by organics. Furthermore, Fuentes et al. (2011) found 
a depression in CCN activity of 5-24\% in seawater enriched with marine organics compared with unenriched seawater. When applying Koehler theory to measurements of purely organic algal exudates, $\kappa$ values between 0.06 and 0.16 were found by Fuentes et al. (2011), which fits well with our upper value. Assuming that $\kappa_{\text {org }}$ is in a range between 0 and 0.2 and varying the other parameters as described in Table 2 we find that $\kappa_{\text {tot }}$ lies in a range between $0.33 \pm 0.13$ and $0.50 \pm 0.11$.

The same permutations have also been applied for the analysis of the data from counter 2. The comparison of the $0.20 \%$ SS-data from the first counter and $0.22 \%$ SS-data from the second counter shows good agreement within the uncertainties (Fig. 6). Note that the actual supersaturation of counter 1 is not constant in time. The times at which the two counters measured at the considered supersaturations were also different, as counter 1 was changing its supersaturation every $30 \mathrm{~min}$ and counter 2 started to measure at $0.22 \% \mathrm{SS}$ only from 15 August onwards. However, the slope closest to 1 was again achieved with the same parameter settings, namely sensitivity permutation 13 (see Table A1).

As counter 2 was only measuring for four days on the ice floe with a supersaturation of $0.17 \%$, the comparison with the $0.15 \%$ SS data from counter 1 is less significant, however, a linear fit from those data sets (counter 2 vs. counter 1 ) lead to a slope of 0.99 .

$\mathrm{CCN}_{\text {pred }} / \mathrm{CCN}_{\text {meas }}$ against the time on the ice floe from the best fit (permutation 13) is shown in Fig. 7. During a rather long time period from DoY 233.9 to 238.1, many outliers are found at the two highest supersaturations. The calculated CCN numbers are mainly underpredicted there, assuming that the particles should be considered to be more hygroscopic to achieve closure. The $\kappa$ value varied between 0.1 and 0.4 over this time period. But again, since the AMS only measures particles larger than $70 \mathrm{~nm}$ in diameter, the small particles might have had a different composition then. The HTDMA data show similar growth factors for this time than during other times. Furthermore, the numerous outliers found for the highest two $S S$ during this time period point to a larger uncertainty in the closure. The underprediction might be caused by the pronounced Aitken mode that is then seen in the size distribution data, if the measured chemistry for particles $>70 \mathrm{~nm}$ is not appropriate for this Aitken mode.

The time series of $\kappa_{\text {tot }}$ from the best fit (permutation 13) is shown in Fig. $8 . \kappa_{\text {tot }}$ exhibits a large variability, ranging from 0.09 to 0.61 (the latter value is reached when no organic mass at all was measured). The mean value over the entire campaign is 0.33 with a standard deviation $(1-\sigma)$ of \pm 0.13 which corresponds to about $50 \%$ of the mean value, making it not very representative of the hygroscopic properties for the total investigated time period. In a recent paper, Pringle et al. (2010) modeled the $\kappa$ value globally and found an annual mean for the Arctic region of between 0.4 and 0.5. They used the ECHAM-MESSy Atmospheric Chemistry Model (EMAC) with seven aerosol classes (sulfate, black carbon,

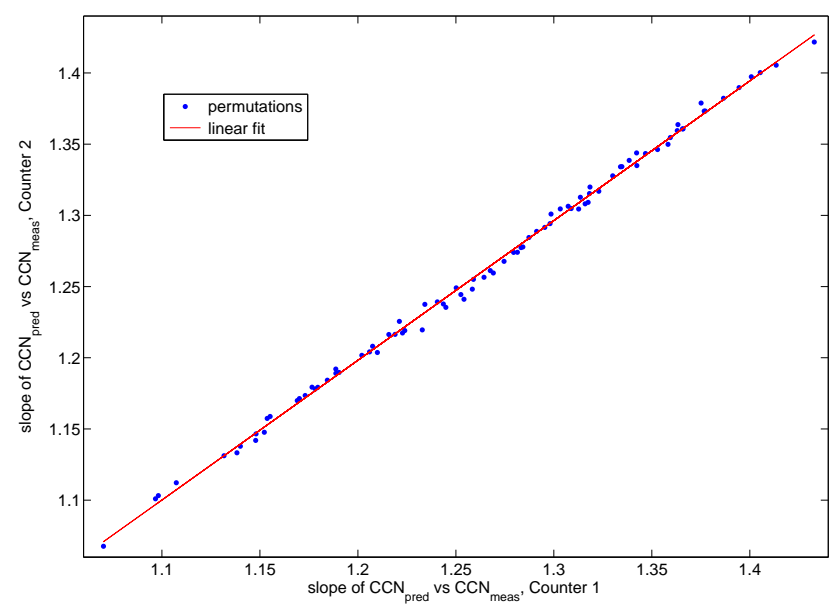

Fig. 6. The comparison of the permutation results of the first and the second CCN counter for $0.20 \% S S$ and $0.22 \% S S$, respectively. The slope of the linear fit was 0.98 , thus represents a very good correlation.

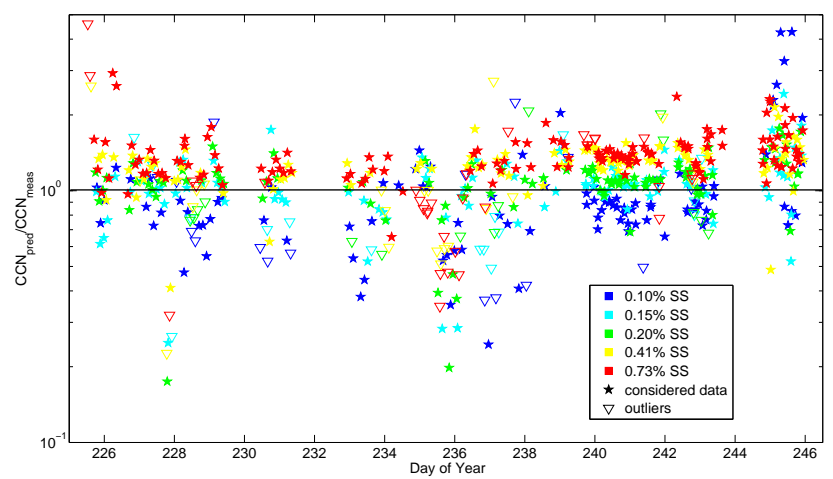

Fig. 7. Time series of $\mathrm{CCN}_{\text {pred }} / \mathrm{CCN}_{\text {meas }}$ for the five supersaturation using the parameters of permutation $13\left(\kappa_{\text {org }}=0.0, \kappa_{\text {sulf }}=\right.$ $0.61, \rho_{\text {org }}=1 \mathrm{~g} \mathrm{~cm}^{-3}$ ).

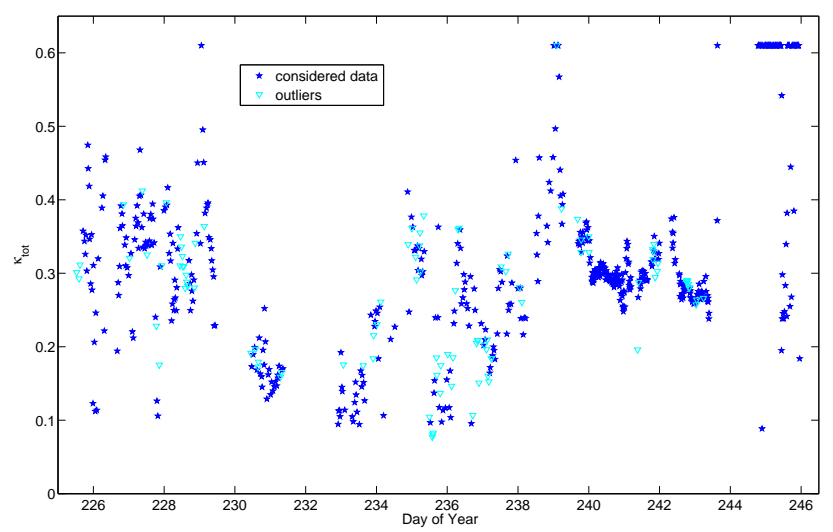

Fig. 8. The time series of the total $\kappa$ value using the parameters of permutation $13\left(\kappa_{\text {org }}=0.0, \kappa_{\text {sulf }}=0.61, \rho_{\text {org }}=1 \mathrm{~g} \mathrm{~cm}^{-3}\right)$. 
organic carbon, nitrate, ammonium, dust, sea salt) in several hydrophilic and hydrophobic modes and in the nucleation, Aitken, accumulation and coarse size range. For the time period while Oden was moored to the ice floe, this model gives a mean $\kappa$ value of $0.26 \pm 0.06$, using the coordinates of the ship route (K. Pringle, personal communication, 2010). This is a lower value than our measured one, but within its standard deviation.

Mean measured CCN number concentrations and standard deviations are shown in Table 3. As one can see, the mean concentrations are very low and also very variable. A more detailed study of $\mathrm{CCN}$ concerning different meteorological conditions will be carried out in a follow-up study. The importance of size-resolved chemistry for the CCN activity will be further studied by performing a $\mathrm{CCN}$ closure based on the hygroscopic growth as measured by the HTDMA. Furthermore, size resolved impactor data are available, which can be used to get further insights into aerosol chemistry.

\section{Conclusions}

An aerosol-cloud condensation nuclei (CCN) closure study based on observed CCN number concentration and physical and chemical submicrometer aerosol properties and concentrations was performed. The data shown here were collected during an expedition into the summer high Arctic (about $87^{\circ} \mathrm{N}$ ) onboard an icebreaker during a three-week time period, when the ship was drifting passively moored to an ice floe. Measured CCN number concentrations at different supersaturations from two $\mathrm{CCN}$ counters were compared with predicted $\mathrm{CCN}$ number concentrations calculated from mass concentration data from an aerosol mass spectrometer and size distributions from a differential mobility particle sizer.

In general, closure was achieved within the measurement uncertainties for $0.10 \%$ supersaturation $(S S), 0.15 \%$ and $0.20 \%$ SS from one counter, that scanned through five different supersaturations (counter 1), assuming an internally mixed aerosol and an insoluble or only sparingly soluble organic volume fraction. For the two highest supersaturations, $0.41 \%$ SS and $0.73 \%$ SS, the predicted CCN numbers were overpredicted for all tested settings, in which the hygroscopicity and the density of the organic fraction was varied, as well as the hygroscopicity of the sulfuric component, and $0 \%$ or $20 \%$ insoluble organic fraction was assumed. One way to explain this is by assuming that the smaller particles have a different composition than the larger ones, presumably a non- hygroscopic or only less hygroscopic organic fraction. A different, less hygroscopic composition of the smaller particles is supported by measurements in the subsaturated regime made with a hygroscopic tandem differential mobility analyzer (HTDMA).
Table 3. The mean CCN concentrations and standard deviations for all five measured supersaturations of counter 1 , averaged over the time period of the ice drift.

\begin{tabular}{rrr}
\hline $\begin{array}{r}\text { Supersaturation } \\
(\%)\end{array}$ & $\begin{array}{r}\text { mean CCN } \\
\text { concentration } \\
\left(\mathrm{cm}^{-3}\right)\end{array}$ & $\begin{array}{r}\text { standard } \\
\text { deviation }\end{array}$ \\
\hline 0.10 & 14.01 & 10.96 \\
0.15 & 19.96 & 15.15 \\
0.20 & 26.55 & 19.63 \\
0.41 & 34.62 & 22.67 \\
0.73 & 46.99 & 37.43 \\
\hline
\end{tabular}

Results from counter 1 at $0.10 \%$ SS give an upper limit of $\kappa_{\text {org }}=0.2$, since the assumption of an organic fraction with a hygroscopic parameter $\kappa>0.2$ results in overpredicted CCN concentrations. This means that the organic fraction of the aerosols was non- or less hygroscopic and does not contribute significantly to droplet growth. The data from counter 1 at $0.20 \%$ SS compared well with that of counter 2 , which was measuring at a constant supersaturation of $0.22 \%$.

The assumptions concerning density and hygroscopicity could not be determined unambiguously, but the best constraints of $\kappa_{\text {org }}=0.02, \kappa_{\text {sulf }}=0.65$, and $\rho_{\text {org }}=1 \mathrm{~g} \mathrm{~cm}^{-3}$ lead to an overall mean $\kappa$ value of $0.33 \pm 0.13$, with the variability in $\kappa$ being rather large. When assuming that $\kappa_{\text {org }} \leq 0.2, \kappa_{\text {tot }}$ falls in a range between $0.33 \pm 0.13$ to $0.50 \pm 0.11$. $\kappa$ showed a large variability throughout the experiment, suggesting that the hygroscopic properties of the aerosol changed during the campaign.

The investigated data represent a $\mathrm{CCN}$-mass closure for a time period of only three weeks, and as there are, to our knowledge, no similar high time resolved measurements of the high Arctic during its most biological active period into autumn freeze up conditions except for the more primitive $\mathrm{CCN}$ closures performed during previous Arctic expeditions, our results can thus not be compared in detail with other data.

For further investigations, the data will be compared with hygroscopicity data measured in the subsaturated regime and size resolved chemical data. Moreover, different time periods will be investigated in more detail by case studies, i.e. taking meteorological conditions and time the air spent over the pack ice region into consideration. 


\section{Appendix A}

Table A1. Table with the different parameter settings for the performed closure studies and the resulting slopes for the five supersaturations. (Settings 1-2, 7-8, 13-14, 91-92, 97-98, 103-104, 181-182, 187-188, 193-194, 271-272, 277-278, 283-284, 361-362, 367-368 and 373-374 lead to the same tested parameters in each case.)

\begin{tabular}{|c|c|c|c|c|c|c|c|c|c|}
\hline $\begin{array}{l}\text { num- } \\
\text { ber }\end{array}$ & $\kappa_{\text {org }}$ & $\kappa_{\text {sulf }}$ & $\begin{array}{c}\rho_{\text {org }} \\
{\left[\mathrm{g} \mathrm{cm}^{-3}\right]}\end{array}$ & $\begin{array}{r}\rho_{\text {ins }} \\
{\left[\mathrm{g} \mathrm{cm}^{-3}\right]}\end{array}$ & $\begin{array}{r}\text { Slope } \\
0.10 \% S S\end{array}$ & $\begin{array}{r}\text { Slope } \\
0.15 \% S S\end{array}$ & $\begin{array}{r}\text { Slope } \\
0.20 \% S S\end{array}$ & $\begin{array}{r}\text { Slope } \\
0.41 \% \text { SS }\end{array}$ & $\begin{array}{r}\text { Slope } \\
0.73 \% \text { SS }\end{array}$ \\
\hline 1 & 0 & 0.7 & 1 & 1 & $0.94 \pm 0.15$ & $1.12 \pm 0.08$ & $1.14 \pm 0.04$ & $1.33 \pm 0.01$ & $1.37 \pm 0.08$ \\
\hline 2 & 0 & 0.7 & 1 & 0 & $0.94 \pm 0.15$ & $1.12 \pm 0.08$ & $1.14 \pm 0.04$ & $1.33 \pm 0.01$ & $1.37 \pm 0.08$ \\
\hline 3 & 0 & 0.7 & 1.2 & 1 & $0.98 \pm 0.15$ & $1.16 \pm 0.10$ & $1.17 \pm 0.06$ & $1.33 \pm 0.01$ & $1.39 \pm 0.07$ \\
\hline 4 & 0 & 0.7 & 1.2 & 0 & $1.00 \pm 0.16$ & $1.17 \pm 0.08$ & $1.18 \pm 0.07$ & $1.34 \pm 0.01$ & $1.40 \pm 0.08$ \\
\hline 5 & 0 & 0.7 & 1.6 & 1 & $1.06 \pm 0.17$ & $1.21 \pm 0.05$ & $1.22 \pm 0.07$ & $1.36 \pm 0.03$ & $1.43 \pm 0.06$ \\
\hline 6 & 0 & 0.7 & 1.6 & 0 & $1.11 \pm 0.18$ & $1.24 \pm 0.04$ & $1.23 \pm 0.08$ & $1.36 \pm 0.02$ & $1.44 \pm 0.06$ \\
\hline 7 & 0 & 0.65 & 1 & 1 & $0.89 \pm 0.11$ & $1.08 \pm 0.06$ & $1.10 \pm 0.06$ & $1.30 \pm 0.03$ & $1.34 \pm 0.10$ \\
\hline 8 & 0 & 0.65 & 1 & 0 & $0.89 \pm 0.11$ & $1.08 \pm 0.06$ & $1.10 \pm 0.06$ & $1.30 \pm 0.03$ & $1.34 \pm 0.10$ \\
\hline 9 & 0 & 0.65 & 1.2 & 1 & $0.94 \pm 0.16$ & $1.11 \pm 0.09$ & $1.14 \pm 0.04$ & $1.32 \pm 0.01$ & $1.36 \pm 0.09$ \\
\hline 10 & 0 & 0.65 & 1.2 & 0 & $0.95 \pm 0.15$ & $1.12 \pm 0.09$ & $1.15 \pm 0.04$ & $1.33 \pm 0.00$ & $1.38 \pm 0.08$ \\
\hline 11 & 0 & 0.65 & 1.6 & 1 & $1.00 \pm 0.17$ & $1.16 \pm 0.09$ & $1.18 \pm 0.07$ & $1.33 \pm 0.02$ & $1.40 \pm 0.08$ \\
\hline 12 & 0 & 0.65 & 1.6 & 0 & $1.03 \pm 0.18$ & $1.19 \pm 0.07$ & $1.20 \pm 0.08$ & $1.35 \pm 0.02$ & $1.42 \pm 0.07$ \\
\hline 13 & 0 & 0.61 & 1 & 1 & $0.85 \pm 0.10$ & $1.04 \pm 0.08$ & $1.07 \pm 0.08$ & $1.29 \pm 0.01$ & $1.33 \pm 0.09$ \\
\hline 14 & 0 & 0.61 & 1 & 0 & $0.85 \pm 0.10$ & $1.04 \pm 0.08$ & $1.07 \pm 0.08$ & $1.29 \pm 0.01$ & $1.33 \pm 0.09$ \\
\hline 15 & 0 & 0.61 & 1.2 & 1 & $0.89 \pm 0.13$ & $1.08 \pm 0.07$ & $1.10 \pm 0.05$ & $1.31 \pm 0.02$ & $1.34 \pm 0.10$ \\
\hline 16 & 0 & 0.61 & 1.2 & 0 & $0.90 \pm 0.14$ & $1.09 \pm 0.07$ & $1.11 \pm 0.05$ & $1.30 \pm 0.03$ & $1.35 \pm 0.09$ \\
\hline 17 & 0 & 0.61 & 1.6 & 1 & $0.96 \pm 0.15$ & $1.13 \pm 0.09$ & $1.15 \pm 0.05$ & $1.32 \pm 0.01$ & $1.38 \pm 0.08$ \\
\hline 18 & 0 & 0.61 & 1.6 & 0 & $0.99 \pm 0.16$ & $1.15 \pm 0.08$ & $1.17 \pm 0.06$ & $1.35 \pm 0.03$ & $1.39 \pm 0.07$ \\
\hline 19 & 0.1 & 0.7 & 1 & 1 & $1.02 \pm 0.19$ & $1.18 \pm 0.08$ & $1.19 \pm 0.07$ & $1.36 \pm 0.04$ & $1.41 \pm 0.07$ \\
\hline 20 & 0.1 & 0.7 & 1 & 0 & $1.04 \pm 0.21$ & $1.20 \pm 0.06$ & $1.21 \pm 0.07$ & $1.35 \pm 0.02$ & $1.42 \pm 0.06$ \\
\hline 21 & 0.1 & 0.7 & 1.2 & 1 & $1.05 \pm 0.19$ & $1.21 \pm 0.07$ & $1.22 \pm 0.08$ & $1.36 \pm 0.02$ & $1.43 \pm 0.07$ \\
\hline 22 & 0.1 & 0.7 & 1.2 & 0 & $1.09 \pm 0.22$ & $1.24 \pm 0.05$ & $1.24 \pm 0.07$ & $1.38 \pm 0.02$ & $1.44 \pm 0.07$ \\
\hline 23 & 0.1 & 0.7 & 1.6 & 1 & $1.11 \pm 0.23$ & $1.26 \pm 0.02$ & $1.26 \pm 0.08$ & $1.38 \pm 0.01$ & $1.46 \pm 0.05$ \\
\hline 24 & 0.1 & 0.7 & 1.6 & 0 & $1.22 \pm 0.16$ & $1.31 \pm 0.00$ & $1.30 \pm 0.04$ & $1.38 \pm 0.06$ & $1.48 \pm 0.04$ \\
\hline 25 & 0.1 & 0.65 & 1 & 1 & $0.98 \pm 0.16$ & $1.14 \pm 0.10$ & $1.16 \pm 0.07$ & $1.34 \pm 0.04$ & $1.38 \pm 0.08$ \\
\hline 26 & 0.1 & 0.65 & 1 & 0 & $0.99 \pm 0.16$ & $1.16 \pm 0.09$ & $1.17 \pm 0.07$ & $1.35 \pm 0.04$ & $1.39 \pm 0.07$ \\
\hline 27 & 0.1 & 0.65 & 1.2 & 1 & $1.01 \pm 0.17$ & $1.17 \pm 0.08$ & $1.18 \pm 0.08$ & $1.34 \pm 0.02$ & $1.40 \pm 0.07$ \\
\hline 28 & 0.1 & 0.65 & 1.2 & 0 & $1.04 \pm 0.21$ & $1.20 \pm 0.07$ & $1.21 \pm 0.07$ & $1.36 \pm 0.02$ & $1.42 \pm 0.07$ \\
\hline 29 & 0.1 & 0.65 & 1.6 & 1 & $1.06 \pm 0.18$ & $1.21 \pm 0.06$ & $1.22 \pm 0.07$ & $1.36 \pm 0.02$ & $1.42 \pm 0.07$ \\
\hline 30 & 0.1 & 0.65 & 1.6 & 0 & $1.14 \pm 0.19$ & $1.26 \pm 0.02$ & $1.26 \pm 0.07$ & $1.36 \pm 0.02$ & $1.45 \pm 0.05$ \\
\hline 31 & 0.1 & 0.61 & 1 & 1 & $0.94 \pm 0.16$ & $1.11 \pm 0.09$ & $1.13 \pm 0.04$ & $1.33 \pm 0.01$ & $1.37 \pm 0.07$ \\
\hline 32 & 0.1 & 0.61 & 1 & 0 & $0.97 \pm 0.13$ & $1.12 \pm 0.10$ & $1.15 \pm 0.05$ & $1.33 \pm 0.01$ & $1.38 \pm 0.08$ \\
\hline 33 & 0.1 & 0.61 & 1.2 & 1 & $0.98 \pm 0.15$ & $1.14 \pm 0.10$ & $1.15 \pm 0.06$ & $1.33 \pm 0.02$ & $1.38 \pm 0.07$ \\
\hline 34 & 0.1 & 0.61 & 1.2 & 0 & $1.01 \pm 0.15$ & $1.16 \pm 0.09$ & $1.18 \pm 0.07$ & $1.35 \pm 0.03$ & $1.40 \pm 0.06$ \\
\hline 35 & 0.1 & 0.61 & 1.6 & 1 & $1.02 \pm 0.18$ & $1.17 \pm 0.08$ & $1.19 \pm 0.08$ & $1.35 \pm 0.03$ & $1.40 \pm 0.06$ \\
\hline 36 & 0.1 & 0.61 & 1.6 & 0 & $1.08 \pm 0.21$ & $1.22 \pm 0.06$ & $1.22 \pm 0.08$ & $1.36 \pm 0.02$ & $1.43 \pm 0.07$ \\
\hline 37 & 0.2 & 0.7 & 1 & 1 & $1.11 \pm 0.23$ & $1.25 \pm 0.07$ & $1.25 \pm 0.06$ & $1.37 \pm 0.00$ & $1.45 \pm 0.05$ \\
\hline 38 & 0.2 & 0.7 & 1 & 0 & $1.19 \pm 0.17$ & $1.29 \pm 0.01$ & $1.28 \pm 0.06$ & $1.38 \pm 0.04$ & $1.47 \pm 0.08$ \\
\hline 39 & 0.2 & 0.7 & 1.2 & 1 & $1.17 \pm 0.18$ & $1.28 \pm 0.01$ & $1.27 \pm 0.06$ & $1.38 \pm 0.02$ & $1.46 \pm 0.08$ \\
\hline 40 & 0.2 & 0.7 & 1.2 & 0 & $1.27 \pm 0.14$ & $1.32 \pm 0.01$ & $1.30 \pm 0.05$ & $1.40 \pm 0.05$ & $1.50 \pm 0.06$ \\
\hline 41 & 0.2 & 0.7 & 1.6 & 1 & $1.25 \pm 0.14$ & $1.32 \pm 0.00$ & $1.30 \pm 0.05$ & $1.39 \pm 0.05$ & $1.49 \pm 0.05$ \\
\hline 42 & 0.2 & 0.7 & 1.6 & 0 & $1.34 \pm 0.18$ & $1.37 \pm 0.05$ & $1.35 \pm 0.06$ & $1.42 \pm 0.05$ & $1.51 \pm 0.03$ \\
\hline 43 & 0.2 & 0.65 & 1 & 1 & $1.07 \pm 0.21$ & $1.21 \pm 0.08$ & $1.22 \pm 0.07$ & $1.37 \pm 0.01$ & $1.42 \pm 0.07$ \\
\hline 44 & 0.2 & 0.65 & 1 & 0 & $1.14 \pm 0.18$ & $1.25 \pm 0.04$ & $1.25 \pm 0.07$ & $1.36 \pm 0.00$ & $1.45 \pm 0.06$ \\
\hline 45 & 0.2 & 0.65 & 1.2 & 1 & $1.10 \pm 0.21$ & $1.23 \pm 0.08$ & $1.24 \pm 0.06$ & $1.36 \pm 0.00$ & $1.43 \pm 0.07$ \\
\hline
\end{tabular}


Table A1. Continued.

\begin{tabular}{|c|c|c|c|c|c|c|c|c|c|}
\hline $\begin{array}{l}\text { num- } \\
\text { ber }\end{array}$ & $\kappa_{\text {org }}$ & $\kappa_{\text {sulf }}$ & $\begin{array}{r}\rho_{\text {org }} \\
{\left[\mathrm{g} \mathrm{cm}^{-3}\right]}\end{array}$ & $\begin{array}{r}\rho_{\text {ins }} \\
{\left[\mathrm{g} \mathrm{cm}^{-3}\right]}\end{array}$ & $\begin{array}{r}\text { Slope } \\
0.10 \% \text { SS }\end{array}$ & $\begin{array}{r}\text { Slope } \\
0.15 \% S S\end{array}$ & $\begin{array}{r}\text { Slope } \\
0.20 \% S S\end{array}$ & $\begin{array}{r}\text { Slope } \\
0.41 \% \text { SS }\end{array}$ & $\begin{array}{r}\text { Slope } \\
0.73 \% \text { SS }\end{array}$ \\
\hline 46 & 0.2 & 0.65 & 1.2 & 0 & $1.19 \pm 0.17$ & $1.29 \pm 0.00$ & $1.28 \pm 0.08$ & $1.38 \pm 0.03$ & $1.47 \pm 0.07$ \\
\hline 47 & 0.2 & 0.65 & 1.6 & 1 & $1.16 \pm 0.20$ & $1.26 \pm 0.03$ & $1.27 \pm 0.07$ & $1.37 \pm 0.02$ & $1.46 \pm 0.05$ \\
\hline 48 & 0.2 & 0.65 & 1.6 & 0 & $1.28 \pm 0.17$ & $1.33 \pm 0.00$ & $1.31 \pm 0.06$ & $1.40 \pm 0.06$ & $1.50 \pm 0.08$ \\
\hline 49 & 0.2 & 0.61 & 1 & 1 & $1.04 \pm 0.18$ & $1.17 \pm 0.09$ & $1.19 \pm 0.08$ & $1.36 \pm 0.02$ & $1.41 \pm 0.06$ \\
\hline 50 & 0.2 & 0.61 & 1 & 0 & $1.09 \pm 0.19$ & $1.21 \pm 0.09$ & $1.23 \pm 0.07$ & $1.37 \pm 0.00$ & $1.43 \pm 0.06$ \\
\hline 51 & 0.2 & 0.61 & 1.2 & 1 & $1.06 \pm 0.21$ & $1.20 \pm 0.09$ & $1.21 \pm 0.07$ & $1.36 \pm 0.01$ & $1.41 \pm 0.07$ \\
\hline 52 & 0.2 & 0.61 & 1.2 & 0 & $1.14 \pm 0.19$ & $1.25 \pm 0.04$ & $1.25 \pm 0.06$ & $1.37 \pm 0.00$ & $1.45 \pm 0.06$ \\
\hline 53 & 0.2 & 0.61 & 1.6 & 1 & $1.10 \pm 0.21$ & $1.22 \pm 0.06$ & $1.24 \pm 0.05$ & $1.36 \pm 0.01$ & $1.42 \pm 0.07$ \\
\hline 54 & 0.2 & 0.61 & 1.6 & 0 & $1.22 \pm 0.15$ & $1.30 \pm 0.01$ & $1.29 \pm 0.05$ & $1.38 \pm 0.05$ & $1.48 \pm 0.08$ \\
\hline 55 & 0.3 & 0.7 & 1 & 1 & $1.27 \pm 0.14$ & $1.33 \pm 0.01$ & $1.31 \pm 0.04$ & $1.40 \pm 0.07$ & $1.50 \pm 0.05$ \\
\hline 56 & 0.3 & 0.7 & 1 & 0 & $1.33 \pm 0.15$ & $1.37 \pm 0.06$ & $1.34 \pm 0.06$ & $1.42 \pm 0.06$ & $1.52 \pm 0.03$ \\
\hline 57 & 0.3 & 0.7 & 1.2 & 1 & $1.29 \pm 0.14$ & $1.35 \pm 0.01$ & $1.32 \pm 0.05$ & $1.41 \pm 0.06$ & $1.50 \pm 0.05$ \\
\hline 58 & 0.3 & 0.7 & 1.2 & 0 & $1.37 \pm 0.17$ & $1.39 \pm 0.10$ & $1.37 \pm 0.05$ & $1.43 \pm 0.05$ & $1.54 \pm 0.01$ \\
\hline 59 & 0.3 & 0.7 & 1.6 & 1 & $1.32 \pm 0.17$ & $1.36 \pm 0.05$ & $1.34 \pm 0.06$ & $1.41 \pm 0.05$ & $1.51 \pm 0.05$ \\
\hline 60 & 0.3 & 0.7 & 1.6 & 0 & $1.43 \pm 0.17$ & $1.43 \pm 0.08$ & $1.39 \pm 0.09$ & $1.44 \pm 0.06$ & $1.54 \pm 0.03$ \\
\hline 61 & 0.3 & 0.65 & 1 & 1 & $1.21 \pm 0.14$ & $1.29 \pm 0.00$ & $1.28 \pm 0.06$ & $1.38 \pm 0.04$ & $1.48 \pm 0.05$ \\
\hline 62 & 0.3 & 0.65 & 1 & 0 & $1.29 \pm 0.12$ & $1.34 \pm 0.00$ & $1.32 \pm 0.05$ & $1.40 \pm 0.08$ & $1.51 \pm 0.07$ \\
\hline 63 & 0.3 & 0.65 & 1.2 & 1 & $1.24 \pm 0.13$ & $1.31 \pm 0.02$ & $1.29 \pm 0.04$ & $1.39 \pm 0.06$ & $1.49 \pm 0.06$ \\
\hline 64 & 0.3 & 0.65 & 1.2 & 0 & $1.32 \pm 0.15$ & $1.37 \pm 0.05$ & $1.33 \pm 0.05$ & $1.42 \pm 0.08$ & $1.52 \pm 0.04$ \\
\hline 65 & 0.3 & 0.65 & 1.6 & 1 & $1.27 \pm 0.14$ & $1.33 \pm 0.00$ & $1.31 \pm 0.06$ & $1.40 \pm 0.05$ & $1.49 \pm 0.07$ \\
\hline 66 & 0.3 & 0.65 & 1.6 & 0 & $1.37 \pm 0.16$ & $1.39 \pm 0.09$ & $1.36 \pm 0.05$ & $1.43 \pm 0.07$ & $1.55 \pm 0.03$ \\
\hline 67 & 0.3 & 0.61 & 1 & 1 & $1.16 \pm 0.16$ & $1.26 \pm 0.02$ & $1.26 \pm 0.06$ & $1.37 \pm 0.02$ & $1.46 \pm 0.04$ \\
\hline 68 & 0.3 & 0.61 & 1 & 0 & $1.26 \pm 0.10$ & $1.32 \pm 0.04$ & $1.30 \pm 0.05$ & $1.40 \pm 0.07$ & $1.50 \pm 0.06$ \\
\hline 69 & 0.3 & 0.61 & 1.2 & 1 & $1.20 \pm 0.14$ & $1.28 \pm 0.02$ & $1.27 \pm 0.06$ & $1.38 \pm 0.00$ & $1.46 \pm 0.06$ \\
\hline 70 & 0.3 & 0.61 & 1.2 & 0 & $1.27 \pm 0.11$ & $1.34 \pm 0.02$ & $1.32 \pm 0.04$ & $1.41 \pm 0.08$ & $1.50 \pm 0.06$ \\
\hline 71 & 0.3 & 0.61 & 1.6 & 1 & $1.21 \pm 0.16$ & $1.29 \pm 0.02$ & $1.28 \pm 0.07$ & $1.38 \pm 0.04$ & $1.49 \pm 0.05$ \\
\hline 72 & 0.3 & 0.61 & 1.6 & 0 & $1.33 \pm 0.14$ & $1.38 \pm 0.06$ & $1.34 \pm 0.05$ & $1.42 \pm 0.08$ & $1.53 \pm 0.03$ \\
\hline 73 & 0.4 & 0.7 & 1 & 1 & $1.36 \pm 0.15$ & $1.38 \pm 0.06$ & $1.36 \pm 0.06$ & $1.43 \pm 0.06$ & $1.53 \pm 0.01$ \\
\hline 74 & 0.4 & 0.7 & 1 & 0 & $1.44 \pm 0.17$ & $1.44 \pm 0.08$ & $1.40 \pm 0.07$ & $1.43 \pm 0.06$ & $1.54 \pm 0.05$ \\
\hline 75 & 0.4 & 0.7 & 1.2 & 1 & $1.37 \pm 0.18$ & $1.39 \pm 0.07$ & $1.37 \pm 0.06$ & $1.43 \pm 0.05$ & $1.54 \pm 0.01$ \\
\hline 76 & 0.4 & 0.7 & 1.2 & 0 & $1.46 \pm 0.20$ & $1.44 \pm 0.09$ & $1.41 \pm 0.05$ & $1.47 \pm 0.06$ & $1.58 \pm 0.09$ \\
\hline 77 & 0.4 & 0.7 & 1.6 & 1 & $1.38 \pm 0.17$ & $1.40 \pm 0.10$ & $1.38 \pm 0.05$ & $1.44 \pm 0.05$ & $1.55 \pm 0.04$ \\
\hline 78 & 0.4 & 0.7 & 1.6 & 0 & $1.49 \pm 0.20$ & $1.47 \pm 0.10$ & $1.43 \pm 0.06$ & $1.44 \pm 0.08$ & $1.58 \pm 0.10$ \\
\hline 79 & 0.4 & 0.65 & 1 & 1 & $1.31 \pm 0.11$ & $1.36 \pm 0.02$ & $1.33 \pm 0.04$ & $1.42 \pm 0.07$ & $1.53 \pm 0.05$ \\
\hline 80 & 0.4 & 0.65 & 1 & 0 & $1.40 \pm 0.16$ & $1.41 \pm 0.07$ & $1.38 \pm 0.09$ & $1.44 \pm 0.07$ & $1.55 \pm 0.06$ \\
\hline 81 & 0.4 & 0.65 & 1.2 & 1 & $1.32 \pm 0.13$ & $1.37 \pm 0.05$ & $1.33 \pm 0.05$ & $1.42 \pm 0.07$ & $1.52 \pm 0.04$ \\
\hline 82 & 0.4 & 0.65 & 1.2 & 0 & $1.43 \pm 0.17$ & $1.43 \pm 0.07$ & $1.39 \pm 0.07$ & $1.45 \pm 0.06$ & $1.56 \pm 0.06$ \\
\hline 83 & 0.4 & 0.65 & 1.6 & 1 & $1.34 \pm 0.14$ & $1.37 \pm 0.06$ & $1.35 \pm 0.05$ & $1.42 \pm 0.06$ & $1.52 \pm 0.04$ \\
\hline 84 & 0.4 & 0.65 & 1.6 & 0 & $1.46 \pm 0.18$ & $1.44 \pm 0.08$ & $1.41 \pm 0.06$ & $1.44 \pm 0.07$ & $1.57 \pm 0.09$ \\
\hline 85 & 0.4 & 0.61 & 1 & 1 & $1.28 \pm 0.09$ & $1.34 \pm 0.04$ & $1.31 \pm 0.04$ & $1.40 \pm 0.09$ & $1.49 \pm 0.05$ \\
\hline 86 & 0.4 & 0.61 & 1 & 0 & $1.36 \pm 0.15$ & $1.39 \pm 0.07$ & $1.36 \pm 0.06$ & $1.44 \pm 0.07$ & $1.51 \pm 0.05$ \\
\hline 87 & 0.4 & 0.61 & 1.2 & 1 & $1.28 \pm 0.10$ & $1.34 \pm 0.03$ & $1.32 \pm 0.04$ & $1.40 \pm 0.08$ & $1.50 \pm 0.06$ \\
\hline 88 & 0.4 & 0.61 & 1.2 & 0 & $1.39 \pm 0.14$ & $1.41 \pm 0.06$ & $1.36 \pm 0.06$ & $1.43 \pm 0.07$ & $1.53 \pm 0.04$ \\
\hline 89 & 0.4 & 0.61 & 1.6 & 1 & $1.29 \pm 0.12$ & $1.36 \pm 0.02$ & $1.32 \pm 0.04$ & $1.40 \pm 0.08$ & $1.51 \pm 0.07$ \\
\hline 90 & 0.4 & 0.61 & 1.6 & 0 & $1.42 \pm 0.15$ & $1.43 \pm 0.02$ & $1.38 \pm 0.08$ & $1.43 \pm 0.10$ & $1.56 \pm 0.09$ \\
\hline
\end{tabular}


Acknowledgements. This work is part of ASCOS (the Arctic Summer Cloud-Ocean Study). ASCOS was made possible by funding from the Knut and Alice Wallenberg Foundation and the DAMOCLES European Union 6th Framework Program Integrated Research Project. The Swedish Polar Research Secretariat (SPRS) provided access to the icebreaker Oden and logistical support. We are grateful to the SPRS logistical staff and to Oden's Captain Mattias Peterson and his crew. ASCOS is an IPY project under the AICI-IPY umbrella and an endorsed SOLAS project. The authors would like to thank Douglas Orsini for providing the TDMPS data and for useful discussions, and Peter Spichtinger for help with the mathematical analysis of the data and for useful discussions. We thank Kirsty Pringle for running her model with our data. The TDMPS measurements were funded by the German Research Foundation No. HE939/29-1. The AMS measurements were supported by Arctic-SOLAS (Canada), Environment Canada, CFCAS (CAFC Network), NSERC (CGS D for RC), Richard Leaitch, Shao-Meng Li, Katherine Hayden and Dave Halpin. Additionally, we acknowledge financial support from the EU project EUCAARI (European Integrated project on Aerosol Cloud Climate and Air Quality interactions) No. 036833-2.

Edited by: G. de Leeuw

\section{References}

Andreae, M. O. and Rosenfeld, D.: Aerosol-cloudprecipitation interactions, Part 1, The nature and sources of cloud-active aerosols, Earth-Sci. Rev., 89, 13-41, doi:10.1016/j.earscirev.2008.03.001, 2008.

Bigg, E. K. and Leck, C.: Cloud-active particles over the central Arctic Ocean, J. Geophys. Res., 106, 32155-32166, 2001.

Bigg, E. K., Leck, C., and Nilsson, E. D.: Sudden changes in arctic atmospheric aerosol concentrations during summer and autumn, Tellus 48B, 254-271, 1996.

Bigg, E. K., Leck, C., and Nilsson, E. D.: Sudden Changes in Aerosol and Gas concentrations in the central Arctic Marine Boundary Layer - Causes and Consequences, J. Geophys. Res., 106, 32,167-32,185, 2001.

Birmili, W., Stratmann, F., and Wiedensohler, A.: Design of a DMA-based size s pectrometer for a large particle size range and stable operation, J. Aerosol Sci., 30, 549-553, 1999.

Canagaratna, M. R., Jayne, J. T.,Jimenez, J. L., Allan, J. D., Alfarra, M. R., Zhang, Q., Onasch, T. B., Drewnick, F., Coe, H., Middlebrook, A. M., Delia, A. E., Williams, L. R., Trimborn, A. M., Northway, M. J., DeCarlo, P. F., Kolb, C. E., Davidovits, P., and Worsnop, D. R.: Chemical and microphysical characterization of ambient aerosols with the Aerodyne aerosol mass spectrometer, Mass Spec. Rev., 26, 185-222, 2007.

Ceburnis, D., O’Dowd, C. D., Jennings, G. S., Facchini, M. C., Emblico, L., Decesari, S., Fuzzi, S., and Sakalys, J.: Marine aerosol chemistry gradients: Elucidating primary and secondary processes and fluxes, Geophys. Res. Lett., 35, L07804, doi:10.1029/2008GL033462, 2008.

Chang, R. Y.-W., Leck, C., Graus, M., Müller, M., Paatero, J., Burkhart, J. F., Stohl, A., Orr, L. H., Hayden, K., Li, S.-M., Hansel, A., Tjernström, M., Leaitch, W. R., and Abbatt, J. P. D.: Aerosol composition and sources in the central Arctic
Ocean during ASCOS, Atmos. Chem. Phys., 11, 10619-10636, doi:10.5194/acp-11-10619-2011, 2011.

Charlson, R. J., Lovelock, J. E., Andreae, M. O., and Warren, S. G.: Oceanic Phytoplankton, Atmospheric Sulfur, Cloud Albedo and Climate, Nature, 326, 655-661, 1987.

Covert, D. S., Wiedensohler, A., Aalto, P. P., Heintzenberg, J., McMurry, P. H., and Leck, C.: Aerosol number size distributions from 3 to $500 \mathrm{~nm}$ diameter in the arctic marine boundary layer during summer and autumn, Tellus 48B, 197-212, 1996.

Denman, K., Brasseur, G., Chidthaisong, A., Ciais, P., Cox, P., Dickinson, R., Hauglustaine, D., Heinze, C., Holland, E., Jacob, D., Lohmann, U., Ramachandran, S., Silva Dias, P., Wofsy, S., and Zhang, X.: Couplings between changes in the climate system and biogeochemistry, Climate Change 2007: The Physical Science Basis. Contribution of Working Group I to the Fourth Assessment Report of the Intergovernmental Panel on Climate Change, 499-588, edited by: Solomon, S., Qin, D., Manning, M., Chen, Z., Marquis, M., Averyt, K. B., Tignor, M., and Miller, H. L., Cambridge Univ. Press, Cambridge, United Kingdom and New York, NY, USA, 2007.

Drewnick, F., Hings, S. S., DeCarlo, P., Jayne, J. T., Gonin, M., Fuhrer, K., Weimer, S., Jimenez, J. L., Demerjian, K. L., Borrmann, S., and Worsnop, D. R.: A new time-of-flight aerosol mass spectrometer (TOF-AMS) - Instrument description and first field deployment, Aerosol Sci. Technol., 39, 637-658, 2005.

Facchini, M. C., Rinaldi, M., Decesari, S., Carbone, C., Finessi, E., Mircea, M., Fuzzi, S., Ceburnis, D., Flanagan, R., Nilsson, E. D., de Leeuw, G., Martino, M., Woeltjen, J., and O’Dowd, C. D.: Primary submicron marine aerosol dominated by insoluble organic colloids and aggregates, Geophys. Res. Lett., 35, L17814, doi:10.1029/2008GL034210, 2008.

Fors, E. O., Swietlicki, E., Svenningsson, B., Kristensson, A., Frank, G. P., and Sporre, M.: Hygroscopic properties of the ambient aerosol in southern Sweden - a two year study, Atmos. Chem. Phys., 11, 8343-8361, 2011, http://www.atmos-chem-phys.net/11/8343/2011/.

Fuentes, E., Coe, H., Green, D., and McFiggans, G.: On the impacts of phytoplankton-derived organic matter on the properties of the primary marine aerosol - Part 2: Composition, hygroscopicity and cloud condensation activity, Atmos. Chem. Phys., 11, 25852602, doi:10.5194/acp-11-2585-2011, 2011.

Gysel, M., McFiggans, G. B., and Coe, H.: Inversion of tandem differential mobility analyser (TDMA) measurements, J. Aerosol Sci., 40, 134-151, doi:10.1016/j.jaerosci.2008.07.013, 2009.

Heintzenberg, J., and Leck, C.: Seasonal variations of the atmospheric aerosol near the top of the marine boundary layer over Spitsbergen related to the Arctic sulfur cycle, Tellus 46B, 52-67, 1994.

Heintzenberg, J., Leck, C., Birmili, W., Wehner, B., Tjernström, M., and Wiedensohler A.: Aerosol number-size distributions during clear and fog periods in the summer high Arctic: 1991, 1996 and 2001, Tellus B, 58, 41-50, doi:10.1111/j.16000889.2005.00171.x, 2006.

Held, A., Held, A., Brooks, I. M., Leck, C., and Tjernström, M.: On the potential contribution of open lead particle emissions to the central Arctic aerosol concentration, Atmos. Chem. Phys., 11, 3093-3105, doi:10.5194/acp-11-3093-2011, 2011.

Intrieri, J. M., Shupe, M. D., Uttal, T., and McCarty, B. J.: An annual cycle of Arctic cloud characteristics observed by 
radar and lidar at SHEBA, J. Geophys. Res., 107, 8030, doi:10.1029/2000JC000423, 2002.

Jimenez, J. L., Jayne, J. T., Shi, Q., Kolb, C. E., Worsnop, D. R., Yourshaw, I., Seinfeld, J. H., Flagan, R. C., Zhang, X., Smith, K. A., Morris, J. W., and Davidovits, P.: Ambient aerosol sampling using the Aerodyne Aerosol Mass Spectrometer, J. Geophys. Res., 108, 8425, doi:10.1029/2001JD001213, 2003.

Kammermann, L., Gysel, M., Weingartner, E., Herich, H., Cziczo, D. J., Holst, T., Svenningsson, B., Arneth, A., and Baltensperger, U.: Subarctic atmospheric aerosol composition: 3. Measured and modeled properties of cloud condensation nuclei, J. Geophys. Res., 115, D04202, doi:10.1029/2009JD012447, 2010.

Kay, J. E. and Gettelman, A.: Cloud influence on and response to seasonal Arctic sea ice loss, J. Geophys. Res., 114, D18204, doi:10.1029/2009JD011773, 2009.

Korhonen, H., Carslaw, K. S., Spracklen, D. V., Ridley, D. A., and Strom, J.: A global model study of processes controlling aerosol size distributions in the Arctic spring and summer, J. Geophys. Res., 113, D08211, doi:10.1029/2007JD009114, 2008.

Lannefors, H., Heintzenberg, J., and Hansson, H. C.: A comprehensive study of physical and chemical parameters of the Arctic summer aerosol; results from the Swedish expedition Ymer-80, Tellus, 35B, 40-54, 1983.

Leck, C. and Bigg, E. K.: Biogenic particles in the surface microlayer and overlaying atmosphere in the central Artic ocean during summer, Tellus, 57B, 305, 305-316, 2005a.

Leck, C. and Bigg, E. K.: Source and evolution of the marine aerosol - a new perspective, Geophys. Res. Lett., 32, L19803, doi:10.1029/2005GL023651, 2005b.

Leck, C. and Persson, C.: The central Arctic Ocean as a source of dimethyl sulfide-Seasonal variability in relation to biological activity, Tellus B, 48, 156-177, 1996.

Leck, C., Bigg, E. K., Covert, D. S., Heintzenberg, J., Maenhaut, W., Nilsson, E. D., and Wiedensohler, A.: Overview of the Atmospheric research program during the International Arctic Ocean Expedition 1991 (IAOE-91) and its scientific results, Tellus, 48B, 136-155, 1996.

Leck, C., Nilsson, E. D., Bigg, E. K., and Bäcklin, L.: Atmospheric program on the Arctic Ocean Expedition 1996 (AOE-96): An overview of scientific goals, experimental approach, and instruments, J. Geophys. Res., 106, 32051-32067, 2001.

Leck, C., Norman, M., Bigg, E. K., and Hillamo, R.: Chemical composition and sources of the high Arctic aerosol relevant for fog and cloud formation, J. Geophys. Res., 107, doi:10.1029/2001JD001463, 4135, 2002.

Leck, C., Tjernström, M., Matrai, P., Swietlicki, E., and Bigg, E. K.: Can Marine Micro-organisms Influence Melting of the Arctic Pack Ice?, Eos, 85, 3, 25-36, 2004.

Li, S. M. and Barrie, L. A.: Biogenic sulphur aerosol in the Arctic troposphere: 1. Contributions to total sulfate, J. Geophys. Res., 98, 20613-20622, 1993.

Lohmann, U. and Feichter, J.: Global indirect aerosol effects: a review, Atmos. Chem. Phys., 5, 715-737, doi:10.5194/acp-5-7152005, 2005.

Lohmann, U. and Leck, C.: Importance of submicron surface-active organic aerosols for pristine Arctic clouds, Tellus B, 57, 261268, 2005

Mauritsen, T., Sedlar, J., Tjernström, M., Leck, C., Martin, M., Shupe, M., Sjogren, S., Sierau, B., Persson, P. O. G., Brooks,
I. M., and Swietlicki, E.: An Arctic CCN-limited cloud-aerosol regime, Atmos. Chem. Phys., 11, 165-173, doi:10.5194/acp-11165-2011, 2011.

Moore, R., Ingall, E., Sorooshian, A. and Nenes, A.: Molar mass, surface tension, and droplet growth kinetics of marine organics from measurements of CCN activity, Geophys. Res. Lett., 35, L07801, doi:10.1029/2008GL033350, 2008.

Muhlbauer, A., Spichtinger, P., and Lohmann, U.: Application and Comparison of Robust Linear Regression Methods for Trend Estimation, J. Appl. Meteor. Climatol., 48, 1961-1970, 2009.

Nilsson, E. D. and Leck, C.: A pseudo-Lagrangian study of the arctic remote marine sulfur cycle, Tellus, 54B, 213-230, 2002.

Paatero, J., Vaattovaara, P., Vestenius, M., Meinander, O., Makkonen, U., Kivi, R., Hyvärinen, A., Asmi, E., Tjernström, M., and Leck, C.: Finnish contribution to the Arctic Summer Cloud Ocean Study (ASCOS) expedition, Arctic Ocean 2008, Geophysica, 45, 119-146, 2009.

Petters, M. D. and Kreidenweis, S. M.: A single parameter representation of hygroscopic growth and cloud condensation nucleus activity, Atmos. Chem. Phys., 7, 1961-1971, doi:10.5194/acp-71961-2007, 2007.

Pringle, K. J., Tost, H., Pozzer, A., Pöschl, U., and Lelieveld, J.: Global distribution of the effective aerosol hygroscopicity parameter for CCN activation, Atmos. Chem. Phys., 10, 52415255, doi:10.5194/acp-10-5241-2010, 2010.

Quinn, P. K., Miller, T. L., Bates, T. S., Ogren, J. A., Andrews, E., and Shaw, G. E.: A three-year record of simultaneously measured aerosol chemical and optical properties at Barrow, Alaska, J. Geophys. Res., 107, 4130, doi:10.1029/2001JD001248, 2002.

Roberts, G. C. and Nenes, A.: A Continuous-Flow Streamwise Thermal-Gradient CCN Chamber for Atmospheric Measurements, Aerosol Sci. Technol., 39, 206-221, doi:10.1080/027868290913988, 2005.

Rose, D., Gunthe, S. S., Mikhailov, E., Frank, G. P., Dusek, U., Andreae, M. O., and Pöschl, U.: Calibration and measurement uncertainties of a continuous-flow cloud condensation nuclei counter (DMT-CCNC): CCN activation of ammonium sulfate and sodium chloride aerosol particles in theory and experiment, Atmos. Chem. Phys., 8, 1153-1179, doi:10.5194/acp-8-11532008, 2008.

Rousseeuw, P. J.: Least Median of Squares Regression, J. Amer. Stat. Assoc., 79(388), 871-880, 1984.

Rousseeuw, P. J. and Van Driessen, K.: Computing LTS Regression for Large Data Sets, Data Min. Knowl. Disc., 12, 29-45, 2006.

Sedlar, J., Tjernström, M., Mauritsen, T., Shupe, M., Brooks, I., Persson, P., Birch, C., Leck, C., Sirevaag, A., and Nicolaus, M.: A transitioning Arctic surface energy budget: the impacts of solar zenith angle, surface albedo and cloud radiative forcing, Clim. Dyn., 1-18, 2010.

Seinfeld, J. H. and Pandis, S. N.: Atmospheric Chemistry and Physics: From Air Pollution to Climate Change, New York, John Wiley \& Sons, Inc., USA, 1998.

Shaw, G. E.: The Arctic Haze Phenomenon, Bull. Amer. Meteor. Soc., 76(12), 2403-2413, 1995.

Stohl, A., Andrews, E., Burkhart, J. F., Forster, C., Herber, A., Hoch, S. W., Kowal, D., Lunder, C., Mefford, T., Ogren, J. A., Sharma, S., Spichtinger, N., Stebel, K., Stone, R., Strom, J., Torseth, K., Wehrli, C., and Yttri, K. E.: Pan-Arctic enhancements of light absorbing aerosol concentrations due to North 
American boreal forest fires during summer 2004, J. Geophys. Res., 111, D22214, doi:10.1029/2006JD007216, 2006.

Tjernström, M., Sedlar, J., and Shupe, M.: How well do regional climate models reproduce radiation and clouds in the Arctic? An evaluation of ARCMIP simulations, J. Clim. Appl. Meteorol., 47, 2405-2422, 2008.

Twomey, S. A.: The influence of pollution on the shortwave albedo of clouds, J. Atmos. Sci., 34, 1149-1152, 1977.
Walsh, J., Kattsov, V., Chapman, W., Govorkova, V., and Pavlova, T.: Comparison of Arctic climate simulations by uncoupled and coupled global models, J. Climate, 15, 1429-1446, 2002.

Zhou, J., Swietlicki, E., Berg, O. H., Aalto, P. P., Hämeri, K., Nilsson, E. D., and Leck, C.: Hygroscopic properties of aerosol particles over the central Arctic Ocean during summer, J. Geophys. Res., 106, 32111-32123, doi:10.1029/2000JD900426, 2001. 